1 Mid-Holocene drying of the U.S. Great Basin recorded in Nevada speleothems

2 Elena Steponaitis ${ }^{1}$, Alexandra Andrews ${ }^{1}$, David McGee ${ }^{1}$, Jay Quade $^{2}$, Yu-Te $\mathrm{Hsieh}^{3}$,

3 Wallace S. Broecker ${ }^{4}$, Bryan N. Shuman ${ }^{5}$, Stephen J. Burns ${ }^{6}$, Hai Cheng ${ }^{7,8}$

4 1. Department of Earth, Atmospheric, and Planetary Sciences, Massachusetts Institute of

5 Technology, Cambridge, MA, USA

6 2. Department of Geosciences, University of Arizona, Tucson, AZ, USA

7 3. Department of Earth Sciences, University of Oxford, Oxford, UK.

8 4. Lamont-Doherty Earth Observatory, Columbia University, New York, NY, USA

9 5. Department of Geology and Geophysics, University of Wyoming, Laramie, WY, USA

10 6. Department of Geosciences, University of Massachusetts Amherst, Amherst, MA,

11 USA

12 7. Department of Earth Sciences, University of Minnesota, Minneapolis, MN, USA

13 8. Institute of Global Environmental Change, Xi' an Jiaotong University, Xi'an, China.

14 *corresponding author: estep@ mit.edu; MIT Bldg E25-629, 45 Carleton St., Cambridge,

15 MA 02142; Phone: (919) 260-2890

16 Keywords: Great Basin; Holocene; speleothems; U-Th dating; paleoclimate

\title{
17 Abstract
}

18 Lake level records point to dramatic changes in Great Basin water balance over

19 the last $25 \mathrm{ka}$, but the timing and pace of Holocene drying in the region remains poorly

20 documented. Here we present stable isotope and trace metal data from two Lehman

21 Caves, NV speleothems that provide a well-dated record of latest Pleistocene to mid-

22 Holocene hydroclimate in the U.S. Great Basin. Together the stalagmites span the

23 interval between $16.4 \mathrm{ka}$ and $3.8 \mathrm{ka}$, with a hiatus from $15.0 \mathrm{ka}$ to $12.7 \mathrm{ka} . \mathrm{Mg} / \mathrm{Ca}$ and

$24 \quad \delta^{13} \mathrm{C}$ covary throughout the records, consistent with control by the extent of degassing

25 and prior calcite precipitation (PCP); measurements of modern cave and soil waters

26 support PCP as the primary control on drip-water trace-element composition. We

27 therefore interpret $\mathrm{Mg} / \mathrm{Ca}$ and $\delta^{13} \mathrm{C}$ as reflecting infiltration rates, with higher values

28 corresponding to drier periods. Both $\mathrm{Mg} / \mathrm{Ca}$ and $\delta^{13} \mathrm{C}$ indicate a wet period at the

29 beginning of the record (12.7-8.2 ka) followed by pronounced drying after 8.2 ka. This

30 mid-Holocene drying is consistent with records from around the western United States, 
31 including a new compilation of Great Basin lake-level records. The strong temporal

32 correspondence with the collapse of the Laurentide ice sheet over Hudson Bay suggests

33 that this drying may have been triggered by northward movement of the winter storm

34 track as a result of ice sheet retreat. However, we cannot rule out an alternative

35 hypothesis that wet early Holocene conditions are related to equatorial Pacific sea-surface

36 temperature. Regardless, our results suggest that Great Basin water balance in the early

37 Holocene was driven by factors other than orbital changes.

\section{1. Introduction}

The Great Basin is a large internally drained region in the western United States

40 that covers large parts of Nevada, Utah, California, and Oregon (Figure 1). Modern

41 climate over much of the Great Basin is arid, with most of its sub-basins unable to sustain

42 permanent lakes; however, the spectacular paleoshorelines and lake deposits in the Great

43 Basin have long been recognized as evidence of dramatic hydrologic changes in the past.

44 As such, the Great Basin has fascinated geologists since the late $19^{\text {th }}$ century, when G. K.

45 Gilbert and I.C. Russell began to unravel the histories of the region's massive paleo-lakes.

46 More recently, developments in the application of radiocarbon, and later, U-series, dating

47 methods have yielded improved chronologies of hydrologic change from the Great Basin.

48 Despite years of research, well-dated Holocene records of hydrological change

49 from the Great Basin remain sparse. Most existing records of past Great Basin hydrology

50 utilize either shoreline and sediment deposits from closed-basin lakes or biological

51 archives like packrat middens. Although they offer valuable information, these types of

52 records do not always provide the temporal resolution necessary to make inferences about 
53 mechanisms of climate change. In addition, lake deposits commonly record wetter

54 conditions during the last glacial period but offer incomplete records of drier conditions

55 during the Holocene.

56 In recent decades, high-precision U-Th dating of speleothems, combined with

57 trace element and stable isotope measurements, has allowed for the development of

58 detailed chronologies of climate change. To date, there are few published speleothem

59 records from in and around the Great Basin (Asmerom et al., 2007; Denniston et al.,

60 2007; Lachniet et al., 2014; Lundeen et al., 2013; Oster et al., 2009; Polyak et al., 2004;

61 Shakun et al., 2011; Wagner et al., 2010), and only a small number of these offer

62 substantial coverage of the Holocene. Well-dated terrestrial records from this region are

63 necessary to better understand the response of Great Basin hydroclimate to changing

64 boundary conditions over the late Quaternary and to assess the representation of regional

65 precipitation patterns in general circulation models simulating past climates.

66 This study presents geochemical $(\mathrm{Mg} / \mathrm{Ca}$ and $\mathrm{Sr} / \mathrm{Ca})$ and stable isotope $\left(\delta^{18} \mathrm{O}\right.$,

$67 \delta^{13} \mathrm{C}$ ) records spanning much of the deglaciation and Holocene from two speleothems

68 from Lehman Caves, Nevada. We interpret these data - and in particular, the $\mathrm{Mg} / \mathrm{Ca}$ and

$69 \delta^{13} \mathrm{C}$ records - as primarily reflecting infiltration rates above the cave, and we present

70 evidence that local infiltration rates are well correlated with water balance changes over a

71 large portion of the Great Basin during the early to mid Holocene. These records provide

72 important constraints on the potential drivers of relatively wet early Holocene conditions

73 and of mid-Holocene drying in the Great Basin.

\section{2. Regional Setting}


76 Lehman Caves is situated on the east flank of the southern Snake Range on the

77 western margin of the Bonneville Basin, at $39^{\circ} 00^{\prime} 20^{\prime \prime} \mathrm{N}, 114^{\circ} 13^{\prime} 13^{\prime \prime} \mathrm{W}$ and $2130 \mathrm{~m}$

78 elevation (Figure 1). Average annual precipitation above the cave is approximately 33

$79 \mathrm{~cm} /$ year (National Park Service). Seasonal recharge in Lehman Caves is dominated by

80 winter precipitation, as evidenced by seasonal changes in drip rates and cave pool levels;

81 dripwater response time is 1-4 weeks (Ben Roberts, National Park Service, personal

82 communication). The cave is situated within a local topographic high in the Pole Canyon

83 limestone such that the great majority of water entering the cave is from infiltration

84 directly above the cave, not from infiltration or run-off from the higher elevations of the

85 Snake Range. Most of the cave network is situated between 30 and $60 \mathrm{~m}$ from the

86 surface (National Park Service). HOBO data loggers (Onset Computer Corporation,

87 Bourne, MA) placed in the cave in 2009-2010 indicate that air temperature and relative

88 humidity in the cave remain approximately constant year round, at $11.0^{\circ} \mathrm{C}$ and

89 approximately $100 \%$, respectively.

90 The Bonneville Basin enclosed a very large $\left(\sim 55,000 \mathrm{~km}^{2}\right)$ lake during the Last

91 Glacial Maximum (LGM) and early deglaciation that lay just to the east of the cave site

92 (Figure 1), reflecting significantly more positive water balance in the region at these

93 times. The rise of Lake Bonneville leading into the LGM has been suggested by a number

94 of studies to reflect the southward displacement of the mean winter storm track by the

95 Laurentide and Cordilleran ice sheets (Antevs, 1952; Bromwich et al., 2004; COHMAP

96 Members, 1988), although Lyle et al. (2012) used coastal precipitation records to suggest

97 that post-LGM precipitation entered the Great Basin from the tropical Pacific. 
98 Superimposed on this response to ice sheet topography, the basin experienced its wettest

99 conditions during ice-rafting events in the North Atlantic, in particular Heinrich events 1

100 and 2 (McGee et al. 2012; Munroe and Laabs 2013; Oviatt 1997). Although the

101 Bonneville Basin is well studied, relatively little is known about the precise timing of

102 hydrological changes in the Great Basin during the latest Pleistocene and early-to-mid-

103 Holocene. Lake levels dropped considerably around $15 \mathrm{ka}$, approximately at the time of

104 the Bølling/Allerød warming in the Northern Hemisphere (Godsey et al., 2011; McGee et

105 al., 2012; Oviatt et al., 1992). The work of Murchison (1989) and Oviatt et al. (2005) on

106 lacustrine deposits indicates a modest rise of the lake known as the Gilbert highstand

107 between $\sim 12.9$ and $11.2 \mathrm{ka}$, a time which is roughly correlative with the Younger Dryas

108 cold event in the Northern Hemisphere (12.9-11.7 ka; Rasmussen et al. 2006). Other

109 studies from the Bonneville Basin, reviewed in section 5.4 below, document the drying of

110 the basin during the early- to mid-Holocene, but the timing and drivers of this drying

111 remain unclear (Madsen et al., 2001; Patrickson et al., 2010).

112

\section{3. Materials and Methods}

\section{$114 \quad 3.1$ Sample collection}

115 Two Lehman Cave stalagmites, WR11 and CDR3, were analyzed for this study

116 (Figure 2). WR11 was collected from the West Room of the cave, located approximately

$11750 \mathrm{~m}$ below the surface (National Park Service); it originally precipitated on a piece of

118 flowstone that had been broken during cave development over the past century. CDR3

119 had been broken during previous cave vandalism and was collected from the part of the 
120 cave known as the Civil Defense Room (Figure 2) that is used for storage of broken

121 stalagmites; the original growth location is thus unknown. The stalagmites were cut,

122 polished and rinsed in deionized water before being sampled.

123 In May 2013 and January 2014, small (10 to $30 \mathrm{~mL}$ ) acid-cleaned HDPE bottles

124 were used to collect drips from soda straws from locations throughout the cave. Water

125 was also collected from standing pools on the cave floor. In addition, soil was sampled

126 over $10-\mathrm{cm}$ intervals at depths ranging from $0-50 \mathrm{~cm}$ from three pits dug above the cave

127 in May 2013.

128

1293.2 U-Th dating of speleothems

130 Dating samples weighing 20-100 mg were drilled from the speleothems using a

131 vertical mill. The resulting powders were weighed, spiked with ${ }^{229} \mathrm{Th}^{233}{ }^{23-}{ }^{236} \mathrm{U}$ tracer,

132 and dissolved. Following the methods of Edwards et al. (1987), U and Th were removed

133 from solution by co-precipitation with Fe oxyhydroxides, redissolved, and eluted

134 separately through $0.5 \mathrm{~mL}$ bed volume columns packed with BioRad AG1-X8 resin. A

135 total procedural blank was included in each set of chemistry (5-10 samples).

$136 \quad \mathrm{U}$ and Th fractions prepared at MIT were measured either on Brown University's

137 Thermo Scientific Neptune Plus multicollector ICP-MS or on the Thermo Scientific

138 Neptune at Woods Hole Oceanographic Institution (WHOI). Samples prepared at the

139 University of Minnesota were analyzed on the Thermo Scientific Neptune at the

140 University of Minnesota. In all locations, samples were introduced using a CETAC

141 Aridus II desolvating nebulizer intake system and a $100 \mu \mathrm{L} / \mathrm{min}$ PFA nebulizer. For 
142 analyses at Brown University and WHOI, ${ }^{234} \mathrm{U}$ and ${ }^{230} \mathrm{Th}$ were measured on the

143 secondary electron multiplier (SEM) and all other isotopes $\left({ }^{233} \mathrm{U},{ }^{235} \mathrm{U},{ }^{236} \mathrm{U},{ }^{238} \mathrm{U},{ }^{229} \mathrm{Th}\right.$,

144 and ${ }^{232} \mathrm{Th}$ ) were measured on the Faraday cups. The retarding potential quadrupole (RPQ)

145 energy filter was not used on the SEM, as we found it reduced the stability of the

146 Faraday-SEM relative yield. Each U sample was bracketed with a $5 \mathrm{ng} / \mathrm{g}$ solution of the

147 CRM112a U isotopic standard to monitor SEM yield. Tailing for both samples and

148 standards was estimated using measurement of half-masses and mass 237 immediately

149 following each on-peak measurement. Each Th analysis was bracketed by an in-house

$150{ }^{229} \mathrm{Th}^{2}{ }^{230} \mathrm{Th}^{-}{ }^{232} \mathrm{Th}$ standard used to monitor mass bias and SEM yield; this standard was

151 calibrated by bracketing with IRMM $3636 \mathrm{a}^{233} \mathrm{U}^{2}{ }^{236} \mathrm{U}$ solution. $2 \% \mathrm{HNO}_{3}$ solution blanks

152 were run bracketing each sample and standard to determine background signal. At the

153 University of Minnesota, samples were analyzed using a peak-jumping routine on the

154 axial SEM following the methods of Shen et al. (2002).

155 Total procedural blanks for various sample sets were less than $0.07 \mathrm{fg}{ }^{230} \mathrm{Th}, 3 \mathrm{pg}$

$156{ }^{232} \mathrm{Th}, 0.03 \mathrm{fg}{ }^{234} \mathrm{U}$, and $10 \mathrm{pg}{ }^{238} \mathrm{U}$. After making corrections for background, blank, mass

157 bias, tailing, and SEM yield, U-Th ages were calculated using the decay constants

158 determined by Jaffey et al. (1971) for ${ }^{238} \mathrm{U}$ and Cheng et al. (2013) for ${ }^{234} \mathrm{U}$ and ${ }^{230} \mathrm{Th}$.

159 Corrections for initial ${ }^{230} \mathrm{Th}$ assumed an initial ${ }^{230} \mathrm{Th} /{ }^{232} \mathrm{Th}$ atomic ratio of $4.4 \pm 2.2 \times 10^{-6}$

160 (Yardley, 1986). Uncertainties from measurements, spike calibration, procedural blanks,

161 SEM yield drift and tailing were propagated to determine the uncertainties reported in

162 Supplementary Table 1. Reported ages do not include uncertainties on U and Th half163 lives.

$164 \quad 3.3$ Speleothem major and trace element measurements 
166 collector Thermo Element2 ICPMS at Woods Hole Oceanographic Institution (WHOI)

167 using a New Wave Research UP $193 \mathrm{~nm}$ excimer laser system. Major and trace elements

168 were measured along the primary growth axis, using previously drilled stable isotope

169 holes for spatial reference. Analyses were taken at $1 \mathrm{~mm}$ spacing (i.e. next to every

170 second stable isotope hole) using a spot size of 100 microns and an integration time of 60

171 seconds. The first 20 seconds of data were discarded.

172 Internal calibration was established by normalization to ${ }^{48} \mathrm{Ca}$, assuming constant

173 calcium content in the sample. Final results reflect corrections for blank intensities and

174 machine drift monitored by external calibration to a solid carbonate standard (USGS

175 MACS-3) with well-characterized compositions (Jochum et al., 2012). Reproducibility

176 was checked through sampling of 23 previously analyzed points along the same

177 horizontal growth plane. Of those measurements, 18 agreed within 5\% and the remaining 1785 agreed within $15 \%$.

1793.4 Stable isotope analyses

180 In WR11, carbonate powders were drilled in a vertical milling machine at $0.5 \mathrm{~mm}$

181 spacing using a digital tachometer readout to ensure regular sample spacing. In CDR3,

182 powders were hand drilled at $0.5 \mathrm{~mm}$ spacing. The powders were dissolved in dehydrated

183 phosphoric acid at $70^{\circ} \mathrm{C}$ in a KIEL-III automated carbonate preparation device and

184 analyzed with a Finnigan MAT 252 gas ratio mass spectrometer at the University of

185 Arizona. $2 \sigma$ uncertainty is approximately $\pm 0.22 \%$ for $\delta^{18} \mathrm{O}$ values and $\pm 0.16 \%$ for $\delta^{13} \mathrm{C}$ 186 values. 
188 Cave waters were diluted by a factor of 500 with $0.5 \mathrm{M}$ ultra-clean nitric acid,

189 spiked with Sc and In at concentrations of $1 \mathrm{ng} / \mathrm{g}$ to monitor yield, and filtered through

$190 \quad 0.45 \mu \mathrm{m}$ PTFE syringe filters to remove any solids. In order to assess dissolved element

191 ratios in soil pore waters, dry soil samples were rinsed following the procedure of Oster

192 et al. (2012). Approximately $30 \mathrm{~g}$ of dry soil were combined with $30 \mathrm{~mL}$ of $18.2 \mathrm{M} \Omega$ de-

193 ionized water in centrifuge tubes for 24 hours. The mixture was then centrifuged, and

194 approximately $1 \mathrm{~mL}$ of this water was diluted by a factor of 100 with $0.5 \mathrm{M}$ ultra-clean

195 nitric acid, then spiked with Sc and In and filtered in the same manner as the cave waters.

196 All waters were analyzed for $\mathrm{Mg}, \mathrm{Sc}, \mathrm{Ca}, \mathrm{Sr}$, and In on a VG Elemental

197 PlasmaQuad 2+ quadrupole ICP-MS at MIT. Bracketing standards with 1:100 ratios of

198 all other elements to Ca were run after every five samples to monitor the relative yield of

199 each element. Uncertainties were estimated by repeat measurements of samples and

200 measurements of multiple $\mathrm{Mg}$ and $\mathrm{Sr}$ isotopes; analytical uncertainties for ratios are $<2 \%$,

201 and reproducibility averaged better than 5\%. Procedural blanks were prepared with each

202 set of waters and were negligible. Oxygen and hydrogen stable isotope ratios of waters

203 were determined on a Picarro L2130-i Analyzer. Results are reported relative to the

204 VSMOW standard and have a reproducibility of better than $0.1 \%$ for $\delta^{18} \mathrm{O}$ and $0.4 \%$ for $205 \delta \mathrm{D}$.

A lake-level database was compiled using published data from 23 locations

208 around the Great Basin. In this database, low lake level was defined as any lake level 
209 more than 0.5 standard deviations below mean lake level. Lake locations and references

210 are included in Supplementary Table 6.

\section{4. Results}

212 4. 1 Sample description

213 WR11 is a translucent speleothem marked by light-colored calcite deposited on a

214 dark brown flowstone, with only light banding visible to the naked eye in some parts of

215 the speleothem (Figure 2). The base of the lighter part of WR11 is morphologically a

216 flowstone and is not included in this study. Flowstone transitions into a speleothem

217 morphology $10 \mathrm{~mm}$ from the base of the light-colored deposit. As banding in the lower

218 part of this speleothem is not visible to the naked eye or in an ordinary light microscope,

219 the morphology of WR11 was determined using a Zeiss 710 confocal microscope at the

220 Whitehead Institute at MIT.

221 CDR3 is a fragment of a larger speleothem. It is more opaque and lighter in color

222 than WR11, with distinct banding visible to the naked eye and in confocal imagery. A

223 depositional hiatus is marked by a transition from opaque white calcite to more

224 translucent, yellow calcite $11 \mathrm{~mm}$ above the base (Figure 2).

225 4.2 U-Th dating of speleothems

226 We obtained twelve ages within WR11 and nine within CDR3 (Supplementary

227 Table 1), all of which were in stratigraphic order. In WR11, U concentrations were

228 between 40 and $300 \mathrm{ng} / \mathrm{g}$, and in CDR3, U concentrations were between 160 and 300

$229 \mathrm{ng} / \mathrm{g}$. Several ages in each stalagmite were replicated by resampling the stalagmite to 
230 determine the reproducibility of MIT protocols and to test for offsets between UMN and

231 MIT (Supplementary Figure 1); replicates are denoted in Supplementary Table 1 by a

232 lowercase letter following the sample number (i.e. WR11-7a). Replicates showed only

233 small offsets (40-200 years) and did not indicate systematic differences between UMN

234 and MIT.

235 Growth rates vary substantially in both CDR3 and WR11 (Figure 3). In CDR3,

236 between $16 \mathrm{ka}$ and $15 \mathrm{ka}$, growth rate is approximately $8 \mathrm{~mm} / \mathrm{kyr}$. Growth ceases at 15.0

$237 \mathrm{ka}$ and resumes around $12.6 \mathrm{ka}$, after which time the speleothem grows at about 30

$238 \mathrm{~mm} / \mathrm{kyr}$ until the record ends at $10.2 \mathrm{ka}$. The onset of stalagmite (as opposed to

239 flowstone) deposition in WR11 occurs at $11.5 \mathrm{ka}$. Between 11.5 and $10.4 \mathrm{ka}$, the growth

240 rate of WR11 is $20 \mathrm{~mm} / \mathrm{kyr}$, comparable with the high $30 \mathrm{~mm} / \mathrm{kyr}$ growth rate in CDR3.

241 After $10.4 \mathrm{ka}$, the growth rate of WR11 decreases to about $7 \mathrm{~mm} / \mathrm{kyr}$.

2434.3 Elemental and stable isotope composition of speleothems

244 In WR11, $\delta^{18} \mathrm{O}$ values range between -12.6 and $-10.0 \%$ and $\delta^{13} \mathrm{C}$ values range

245 between -5.6 and -0.9\% (Figure 4, Supplementary Table 2); $\mathrm{Mg} / \mathrm{Ca}$ ratios range from 2.1

246 to $6.1 \mathrm{mmol} / \mathrm{mol}$ and $\mathrm{Sr} / \mathrm{Ca}$ ratios range from 0.087 to $0.16 \mathrm{mmol} / \mathrm{mol}$ (Figure 4,

247 Supplementary Table 3). In $\mathrm{CDR} 3, \delta^{18} \mathrm{O}$ values range between -13.2 and $-10.0 \%$ and

$248 \delta^{13} \mathrm{C}$ values range between -7.2 and $-2.7 \%$ (Figure 4, Supplementary Table 2); $\mathrm{Mg} / \mathrm{Ca}$

249 ratios range from 1.3 to $2.6 \mathrm{mmol} / \mathrm{mol}$ and $\mathrm{Sr} / \mathrm{Ca}$ ratios range from 0.083 to 0.14

$250 \mathrm{mmol} / \mathrm{mol}$ (Figure 4, Supplementary Table 3). 
$254 \mathrm{~mol} / \mathrm{mol} ; \mathrm{Sr} / \mathrm{Ca}$ is between approximately 0.40 and $6.3 \mathrm{mmol} / \mathrm{mol}$ (Supplementary Table

255 4). $\mathrm{Mg} / \mathrm{Ca}$ and $\mathrm{Sr} / \mathrm{Ca}$ ratios in cave waters covary (Figure 5). Soil washes return ratios

256 similar to the lowest ratios measured in cave waters, with $\mathrm{Mg} / \mathrm{Ca}$ ranging from 0.053 to

$257 \quad 0.14 \mathrm{~mol} / \mathrm{mol}$ and $\mathrm{Sr} / \mathrm{Ca}$ from 0.72 to $2.1 \mathrm{mmol} / \mathrm{mol}$. Ratios generally increase with soil

258 depth (Supplementary Table 4). Cave water $\delta^{18} \mathrm{O}$ values range from -13.2 to $-10.0 \%$; $\delta \mathrm{D}$

259 values range from -101.8 to $-82.4 \%$ (Supplementary Table 4 ). $\delta^{18} \mathrm{O}$ values of cave drip

260 and pool waters sampled in May 2013 average $-11.9 \pm 0.1 \%$ VSMOW (1 standard error

261 of the mean; $n=18$ ) after exclusion of one sample taken closest to the natural entrance

262 with a $\delta^{18} \mathrm{O}$ value of $-10.0 \%$. This average value is similar to the isotopic composition

263 of winter precipitation above the caves (Bryan Hamilton, National Park Service,

264 unpublished data).

\section{5. Discussion}

\subsection{Interpretation of elemental records}

High $\mathrm{pCO}_{2}$ in soil waters favors the dissolution of carbonate minerals by fluids

268 moving down into the epikarst, via the following reaction:

$$
\mathrm{CaCO}_{3(\mathrm{~s})}+\mathrm{CO}_{2(\mathrm{~g})}+\mathrm{H}_{2} \mathrm{O}_{(\mathrm{aq})} \rightarrow \mathrm{Ca}^{2+}{ }_{\text {(aq) }}+2 \mathrm{HCO}_{3}^{-}{ }_{(\mathrm{aq})}
$$

270 In the cave, low $\mathrm{pCO}_{2}$ conditions reverse this chemical reaction; $\mathrm{CO}_{2}$ is released and the

271 fluid begins to precipitate calcite. The behavior of trace elements such as $\mathrm{Mg}$ and $\mathrm{Sr}$ in

272 these reactions is described by the distribution coefficients $\mathrm{D}_{\mathrm{Mg}}$ and $\mathrm{D}_{\mathrm{Sr}}$, which are

273 defined as: 


$$
\mathrm{D}_{\mathrm{x}}=(\mathrm{X} / \mathrm{Ca})_{\text {calcite }} /(\mathrm{X} / \mathrm{Ca})_{\text {fluid }}
$$

275 where $\mathrm{X}=\mathrm{Mg}, \mathrm{Sr} . \mathrm{D}_{\mathrm{Mg}}$ and $\mathrm{D}_{\mathrm{Sr}}$ are both $<1$ (Day and Henderson, 2013), which means,

276 assuming closed-system behavior, that host fluids will become enriched in $\mathrm{Mg}$ and $\mathrm{Sr}$ as

277 calcite precipitation proceeds. Where mixing is negligible, this enrichment follows simple

278 Rayleigh distillation.

279 In drier conditions, longer fluid residence times in the epikarst and slower drip

280 rates from stalactites allow for substantial degassing of $\mathrm{CO}_{2}$ and calcite precipitation

281 before waters reach stalagmites, increasing $\mathrm{Mg} / \mathrm{Ca}$ and $\mathrm{Sr} / \mathrm{Ca}$ ratios in fluids from which

282 speleothems eventually precipitate "downstream" of the epikarst. Conversely, in wetter

283 conditions with higher epikarst recharge rates, less calcite is precipitated in the epikarst,

284 producing fluids with correspondingly lower $\mathrm{Mg} / \mathrm{Ca}$ and $\mathrm{Sr} / \mathrm{Ca}$ ratios. This process is

285 known as prior calcite precipitation (PCP) and is widely viewed as a dominant control on

286 trace element ratios in cave carbonates (Baker et al., 1997; Day and Henderson, 2013;

287 Fairchild et al., 2006; Johnson et al., 2006; Oster et al., 2009; Sinclair et al., 2012;

288 Tremaine and Froelich, 2012).

$289 \mathrm{Mg} / \mathrm{Ca}$ and $\mathrm{Sr} / \mathrm{Ca}$ ratios of shallow soil water above Lehman Cave are similar to

290 the lowest values measured in cave dripwaters, supporting the idea that infiltrating waters

291 start with low ratios and gradually increase as a result of PCP. Consistent with this

292 hypothesis, Rayleigh fractionation curves calculated using distribution coefficients of

$293 \mathrm{D}_{\mathrm{Mg}}(0.0125)$ and $\mathrm{D}_{\mathrm{Sr}}(0.125)$ calculated from Day and Henderson (2013) and measured

294 modern cave temperature of $11^{\circ} \mathrm{C}$ closely match the variation of $\mathrm{Mg} / \mathrm{Ca}, \mathrm{Sr} / \mathrm{Ca}$ and $\mathrm{Ca}$

295 concentrations observed in modern cave waters (Figure 5). 
297 suggests that they undergo differing degrees of PCP in the epikarst. Other possible

298 controls on $\mathrm{Mg} / \mathrm{Ca}$, such as changing soil geochemistry and mixing between different

299 epikarst reservoirs (Fairchild et al., 2006), probably do not play a large role in Lehman

300 Caves due to the thin soil above the cave and uniform bedrock. Because $\mathrm{Mg} / \mathrm{Ca}$ and

$301 \mathrm{Sr} / \mathrm{Ca}$ of dripwaters are different under the same conditions, it is reasonable to expect

302 different elemental ratios between coeval stalagmites; however, we would expect changes

303 to be of the same sign and timing in different stalagmites if epikarst flow is responding to

304 changes in infiltration rates due to regional climate changes. Because of the shape of the

305 fractionation curve, the amplitude of trace element variations will increase at higher mean

306 values of PCP.

$307 \quad$ Tremaine and Froelich (2013) find that $\mathrm{Sr} / \mathrm{Ca}$ and $\mathrm{Mg} / \mathrm{Ca}$ ratios covary in

308 speleothem calcite precipitated on plates from cave dripwaters and attribute this

309 covariation to PCP; Sinclair et al. (2012) present model and empirical data suggesting

310 that PCP results in covariation of $\mathrm{Sr} / \mathrm{Ca}$ and $\mathrm{Mg} / \mathrm{Ca}$. The slope of this covariation depends

311 on the initial $\mathrm{Sr}$ and $\mathrm{Mg}$ contents of the dripwater. In this study, $\mathrm{Sr} / \mathrm{Ca}$ and $\mathrm{Mg} / \mathrm{Ca}$ are

312 well correlated after $\sim 10 \mathrm{ka}$, suggesting a strong control by PCP after this time, but they

313 are not correlated prior to $10 \mathrm{ka}$. Other studies of farmed cave calcite and speleothem

314 calcite find that $\mathrm{Sr} / \mathrm{Ca}$ does not always covary with $\mathrm{Mg} / \mathrm{Ca}$, even when $\mathrm{Mg} / \mathrm{Ca}$ is likely to

315 reflect PCP (e.g., Huang and Fairchild, 2001; Orland et al., 2014). In several cave

316 systems, excess Sr supplied from windblown dust is a likely cause of decoupling between

317 Sr and Mg (Frumkin and Stein, 2004; Li et al., 2005; Orland et al., 2014). We speculate

318 that $\mathrm{Sr} / \mathrm{Ca}$ ratios between 10-16 ka could have been impacted by delivery of aragonite- 
319 rich dust to soils above the cave from newly exposed playa surfaces after the fall of Lake

320 Bonneville and other Great Basin lakes. The greater susceptibility of Sr to control by

321 processes other than PCP is also due to its order-of-magnitude higher partition coefficient

322 (e.g., Day and Henderson, 2013), which causes its enrichment in cave waters during PCP

323 to be substantially less than that for $\mathrm{Mg}$. We therefore focus on the $\mathrm{Mg} / \mathrm{Ca}$ record as an

324 indicator of PCP and thus infiltration rates, but we note that strong covariation with $\mathrm{Sr} / \mathrm{Ca}$

325 exists during the time period from 10-4 ka, which constitutes the main focus of this study.

3275.2 Interpretation of $\delta^{13} C$ and $\delta^{18} O$ values in Lehman Caves stalagmites

$328 \quad$ A variety of factors influence $\delta^{13} \mathrm{C}$ values of speleothem calcite, including

329 temperature (Mühlinghaus et al. 2007, 2009), ratio of $\mathrm{C}_{3}$ to $\mathrm{C}_{4}$ plants on the surface above

330 the cave (Fairchild et al., 2006), and degassing in the epikarst (Bar-Matthews et al. 1996;

331 Fairchild et al. 2006) and cave itself (Fairchild and Baker, 2012). Temperature has only a

332 weak effect on $\delta^{13} \mathrm{C}$, impacting the fractionation factor between $\mathrm{HCO}_{3}^{-}$(aq) and $\mathrm{CaCO}_{3}$ by

$333<0.01 \%$ per degree C. Pollen and midden records from proximal areas suggest that the

334 ratio of $\mathrm{C}_{3}$ to $\mathrm{C}_{4}$ plants is unlikely to have been a major control on this record, as $\mathrm{C}_{3}$

335 plants have been dominant throughout the late Pleistocene and Holocene at sites with

336 elevations similar to the cave (Madsen et al., 2001; Rhode and Madsen, 1995).

337 Vegetation density and respiration rates can also affect $\delta^{13} \mathrm{C}$ of speleothem calcite in the

338 underlying cave (Baldini et al. 2005). Baldini et al. (2005) observed changes in $\delta^{13} \mathrm{C}$ of

339 speleothem calcite up to of up to $2 \%$ resulting from dramatic changes in vegetation cover

340 above a cave. The amplitude of $\delta^{13} \mathrm{C}$ variability in WR11 is around $6 \%$, and the 
341 vegetation changes above Lehman Caves are unlikely to have been as dramatic as those

342 described by Baldini et al. Thus, vegetation density is probably not a dominant control on

$343 \delta^{13} \mathrm{C}$ of Lehman Caves speleothems. The correlation between $\mathrm{Mg} / \mathrm{Ca}$ and $\delta^{13} \mathrm{C}$ records in

344 CDR3 and WR11 (Figure 6) points to degassing of $\mathrm{CO}_{2}$ in the epikarst as the primary

345 control on speleothem $\delta^{13} \mathrm{C}$ values (Fairchild and Baker, 2012; Johnson et al., 2006; Oster

346 et al., 2009). Preferential degassing of ${ }^{12} \mathrm{CO}_{2}$ enriches residual dissolved inorganic carbon

347 (DIC) in ${ }^{13} \mathrm{C}$, increasing $\delta^{13} \mathrm{C}$ values in speleothem calcite. This same degassing also

348 drives $\mathrm{PCP}$, enriching $\mathrm{Mg} / \mathrm{Ca}$ and $\mathrm{Sr} / \mathrm{Ca}$ ratios in waters and leading to $\delta^{13} \mathrm{C}$ and $\mathrm{Mg} / \mathrm{Ca}$

349 covariation.

350 Controls on $\delta^{18} \mathrm{O}$ values of speleothem calcite are complex; they include

351 condensation temperature, precipitation seasonality, precipitation source, precipitation

352 amount, evaporation in the soil and epikarst, cave temperature, and kinetic fractionation

353 during calcite precipitation (Gascoyne, 1992; Goede et al., 1982; Fairchild et al., 2006;

354 Harmon et al., 1978; Hendy and Wilson, 1968; Lachniet 2009; Mickler et al., 2006;

355 Schwarcz et al., 1976; Yonge et al., 1985). $\delta^{18} \mathrm{O}$ and $\delta \mathrm{D}$ measurements of modern drip

356 and pool waters from the interior of the cave (this study) fall on the same local meteoric

357 water line as $\delta^{18} \mathrm{O}$ and $\delta \mathrm{D}$ measurements of precipitation and stream waters near to the

358 cave (Bryan Hamilton, personal communication); this observation, along with the high

359 relative humidity measured in the modern cave, provides at least coarse support that cave

360 waters are not highly evaporated. During the period of overlap between WR11 and CDR3,

361 differences in $\delta^{18} \mathrm{O}$ values between speleothems (Figure 4) are of similar magnitude to

362 the amplitude of variation in the full length of the $\delta^{18} \mathrm{O}$ records, suggesting that $\delta^{18} \mathrm{O}$ in at

363 least one of these stalagmites may not reflect precipitation $\delta^{18} \mathrm{O}$. The strong covariation 
364 between $\delta^{18} \mathrm{O}$ and $\delta^{13} \mathrm{C}$ in WR11 (Figure 6) suggests that $\delta^{18} \mathrm{O}$ in this sample may be 365 impacted by kinetic effects. One mechanism of kinetic fractionation that drives positive $366 \delta^{18} \mathrm{O}-\delta^{13} \mathrm{C}$ covariation is enrichment of the $\mathrm{HCO}_{3 \text { (aq) }}^{-}$pool in ${ }^{18} \mathrm{O}$ by $\mathrm{CO}_{2}$ degassing,

367 followed by calcite precipitation proceeding faster than isotopic exchange between

$368 \mathrm{HCO}_{3}{ }^{-}{ }_{(\mathrm{aq})}$ and $\mathrm{H}_{2} \mathrm{O}$ (Hendy, 1971; Mickler et al., 2006, 2004). This mechanism, which is

369 argued to be common in semi-arid caves (Mickler et al., 2006), ties $\delta^{18} \mathrm{O}$ variations to the

370 same degassing and $\mathrm{PCP}$ that drive $\delta^{13} \mathrm{C}$ and $\mathrm{Mg} / \mathrm{Ca}$ variations, offering an explanation

371 for the $\delta^{18} \mathrm{O}-\delta^{13} \mathrm{C}-\mathrm{Mg} / \mathrm{Ca}$ correlations we observe.

372 In addition to showing poor replication with sample CDR3, the $\delta^{18} \mathrm{O}$ record from

373 WR11 also does not replicate a previously published stalagmite $\delta^{18} \mathrm{O}$ record from

374 Leviathan Cave in Nevada (Figure 7) (Lachniet et al., 2014). The shorter record from

$375 \mathrm{CDR} 3$, which does not show significant covariability between $\delta^{18} \mathrm{O}$ and $\delta^{13} \mathrm{C}$

376 (Supplementary Figure 2), shows reasonable agreement with the overlapping portion of

377 the Leviathan Cave record, but during the mid-Holocene Leviathan Cave $\delta^{18} \mathrm{O}$ values are

378 substantially more positive than values in Lehman Cave sample WR11. This poor

379 reproducibility, along with other studies of $\delta^{18} \mathrm{O}$ in semi-arid regions (Kanner et al., 2014;

380 Mickler et al., 2006), urges caution in linking $\delta^{18} \mathrm{O}$ records from single stalagmites

381 directly to $\delta^{18} \mathrm{O}$ values of precipitation in the Great Basin.

$382 \quad$ Based on the poor reproducibility of $\delta^{18} \mathrm{O}$ records both within and between caves

383 we do not interpret our $\delta^{18} \mathrm{O}$ records as reflecting precipitation $\delta^{18} \mathrm{O}$. Instead, we take the 384 covariation of $\delta^{18} \mathrm{O}, \delta^{13} \mathrm{C}$ and $\mathrm{Mg} / \mathrm{Ca}$ in much of the Lehman Cave record, and in 
385 particular after $10 \mathrm{ka}$, as an indication that $\delta^{18} \mathrm{O}$ in these samples primarily reflects kinetic

386 fractionation related to degassing and PCP (Mickler et al., 2004; 2006).

As detailed in sections 5.1 and 5.2 above, we interpret our trace element and

390 stable isotope records as primarily reflecting infiltration rates above Lehman Caves,

391 which we assume to be related to winter precipitation amount. Reduced infiltration rates

392 allow increased degassing and prior calcite precipitation in the epikarst and in stalactites,

393 resulting in covarying and elevated $\mathrm{Mg} / \mathrm{Ca}, \mathrm{Sr} / \mathrm{Ca}, \delta^{13} \mathrm{C}$ and $\delta^{18} \mathrm{O}$ in speleothem calcite.

394 We suggest that $\mathrm{Mg} / \mathrm{Ca}$ and $\delta^{13} \mathrm{C}$ are most simply related to infiltration rates due to their

395 high sensitivity to degassing and $\mathrm{PCP}$. Sr/Ca (due to its higher distribution coefficient in

396 calcite) and $\delta^{18} \mathrm{O}$ (due to partial buffering by isotopic exchange with oxygen in water) are

397 less strongly impacted and are more likely to reflect other environmental factors, such as

398 dust deposition for $\mathrm{Sr}$ and cave temperature and precipitation $\delta^{18} \mathrm{O}$ for $\delta^{18} \mathrm{O}$.

399 Based on this reasoning, low $\mathrm{Mg} / \mathrm{Ca}$ and $\delta^{13} \mathrm{C}$ values in $\mathrm{CDR} 3$ indicate wet

400 conditions at the end of Heinrich Stadial 1 between 16.4 and $15.0 \mathrm{ka}$, consistent with

401 widespread evidence of wet conditions during this period in the Great Basin (McGee et

402 al., 2012; Munroe and Laabs 2013; Oviatt, 1997). Drying over the interval is suggested

403 by rising $\delta^{13} \mathrm{C}$ values (Figure 8 ). $\mathrm{Mg} / \mathrm{Ca}$ values do not rise, perhaps due to the start of

404 PCP being marked by little enrichment in dripwater $\mathrm{Mg} / \mathrm{Ca}$ (Figure 5) or other previously

405 discussed controls on $\delta^{13} \mathrm{C}$. This drying would be consistent with steadily increasing $\delta^{18} \mathrm{O}$

406 values of Lake Bonneville carbonates over this time period (Benson et al. 2011; McGee 
407 et al. 2012) as well as with the timing of drying in Jakes Lake and Lake Franklin, located

408 approximately $100 \mathrm{~km}$ west of the caves (García and Stokes, 2006; Munroe and Laabs,

409 2013a). The hiatus from 15.0 to $12.7 \mathrm{ka}$ in CDR3 may be suggestive of locally dry

410 conditions during the Bølling-Allerød warm period (14.7-12.9 ka), consistent with Oster

411 et al. (2009) and records from Lake Bonneville (Oviatt et al. 1992; Godsey et al. 2011).

412 The record resumes at $12.7 \mathrm{ka}$ in CDR3, showing similarly wet conditions to the

413 first interval of deposition in both $\mathrm{Mg} / \mathrm{Ca}$ and $\delta^{13} \mathrm{C}$. The speleothem record from WR11

414 begins at $11.5 \mathrm{ka}$ and the CDR3 record ends at $10.2 \mathrm{ka}$. The period of overlap is

415 characterized by similar patterns in $\delta^{13} \mathrm{C}, \mathrm{Mg} / \mathrm{Ca}$ and $\mathrm{Sr} / \mathrm{Ca}$ between the two speleothems.

416 After $10.3 \mathrm{ka}$, the $\mathrm{Mg} / \mathrm{Ca}$ and $\delta^{13} \mathrm{C}$ values in WR11 increase slightly, suggesting slightly

417 drier conditions than during the YD and earliest Holocene. After $8.2 \mathrm{ka}, \mathrm{Mg} / \mathrm{Ca}$ and $\delta^{13} \mathrm{C}$

418 values increase markedly from $8.2 \mathrm{ka}$ until $6.3 \mathrm{ka}$, suggesting a sharp reduction in

419 infiltration rates above the cave. The data suggest that locally dry conditions continue

420 until the end of the record at $3.8 \mathrm{ka}$.

4215.4 Mid-Holocene drying: comparison with regional records

422 The record of hydroclimate changes from Lehman Cave speleothems points to

423 wet conditions beginning at the onset of the Younger Dryas but then persisting well after

424 its end. Inferred highest infiltration rates persist until $10.3 \mathrm{ka}$, followed by moderately

425 drier conditions from 10.3-8.2 $\mathrm{ka}$ and pronounced drying beginning at $8.2 \mathrm{ka}$. The record

426 from WR11 is the only existing speleothem record from the Great Basin that captures and

427 directly dates the onset of drying after this prolonged wet period. However, many other

428 non-speleothem records from the Bonneville Basin and the Great Basin show the same 
429 pattern of an early Holocene wet period followed by a mid-Holocene dry period. Indeed,

430 as early as 1952, Antevs proposed an early-Holocene "anathermal" characterized by slow

431 drying followed by an extremely dry mid-Holocene "altithermal" during which the Great

432 Basin was substantially drier than present day (Antevs, 1952).

433 In reviewing these records we note that different types of records may have

434 varying sensitivities to temperature and precipitation due to differences in elevation and

435 proxy type. For instance, low-elevation paleoecological records may be more sensitive to

436 precipitation than to temperature than high-elevation paleoecological records (Power et

437 al., 2011). We review these diverse records in order to provide a broader view of the

438 timing of regional changes in the Great Basin.

439 Holocene climate changes in the Bonneville Basin have been broadly constrained

440 by the work of many authors (Broughton et al., 2000, 2008; Currey, 1990; Hart et al.,

441 2004; Murchison, 1989; Oviatt, 2005). Radiocarbon dates and sedimentological work on

442 Holocene Lake Bonneville presented by these authors suggest that the lake rose to the

443 Gilbert shoreline sometime after $13 \mathrm{ka}$. In Homestead Cave, located on the west side of

444 the Great Salt Lake, Madsen et al. (2001) observe a marked disappearance of small

445 mammal species in middens after around $9.1 \mathrm{ka}$, potentially associated with drying.

446 About $180 \mathrm{~km}$ north of Lehman Caves, also on the west side of the Bonneville Basin, a

447 pollen record from Blue Lake marsh shows pronounced desiccation after $8.3 \mathrm{ka}$

448 (Louderback and Rhode, 2009).

449 Many recent paleoclimate studies conducted in and around the Great Basin

450 suggest the same general structure of Holocene hydroclimate: wet conditions persisting 
451 during and for a few thousand years after the YD followed by pronounced drying. On the

452 western side of the Great Basin, elemental composition and stable isotope records from a

453 speleothem from Moaning Cave, located in the Sierra Nevada, suggests that wet

454 conditions in the region began near the onset of the YD and persisted until least $10.6 \mathrm{ka}$

455 and possibly as late as $9.6 \mathrm{ka}$ (Oster et al., 2009). Pollen records from Tulare Lake,

456 located to the southwest of Moaning Cave, show a pronounced dry period between 7 and

$4574 \mathrm{ka}$, with wetter conditions before $7 \mathrm{ka}$ (Davis, 1999). Owens Lake, also south of

458 Moaning Cave, rose during the early Holocene from a lowstand during the YD and began

459 to fall again after about $7 \mathrm{ka}$ (Bacon et al., 2006).

460 In southern Nevada, Quade et al. (1998) report the presence of numerous spring-

461 fed "black mats" beginning around $13.8 \mathrm{ka}$, peaking at $11.5 \mathrm{ka}$, and then dropping off

462 completely after around 7.4 ka due to drying. Lachniet et al. (2014) present Holocene

463 speleothem $\delta^{18} \mathrm{O}$ and $\delta^{13} \mathrm{C}$ records from Leviathan Cave, located in south-central Nevada

464 about $170 \mathrm{~km}$ southwest of Lehman Caves. While the $\delta^{18} \mathrm{O}$ record from Leviathan Cave

465 may indicate relevant changes in precipitation source, the $\delta^{13} \mathrm{C}$ record does not show the

466 pattern of mid-Holocene drying shown by our record and the other records summarized

467 here. This difference may be due to control by some of the confounding factors described

468 in section 5.2 (e.g., changes in $\mathrm{C}_{3}$ vs $\mathrm{C}_{4}$ plants), or it may suggest divergent climate

469 histories at the two cave sites.

470 Evidence for a similar hydrological pattern exists in many locations across the

471 western and southwestern United States. In the Guadalupe Mountains of southern New

472 Mexico, Polyak et al. (2004) use speleothem growth as a proxy for wet conditions. Their

473 data suggest a wet period spanning the duration of the YD and lasting until around 10.6 
474 ka. Polyak and Asmerom (2005) demonstrate a lowering of Lake Estancia in central

475 New Mexico around $8.5 \mathrm{ka}$. In northern New Mexico, a pollen and charcoal record from

476 a bog in the Jemez Mountains suggests a wet early Holocene followed by desiccation

477 after about $8.5 \mathrm{ka}$ (Anderson et al., 2008). Pollen and plant macrofossil records show a

478 pronounced wet period in the Kaibab Plateau of northern Arizona between 11 and 8 ka,

479 possibly due to an enhanced summer monsoon (Weng and Jackson, 1999). In central

480 Arizona, pollen, macrofossil, and diatom records from Stoneman Lake shows pronounced

481 drying after approximately 9.4 ka (Hasbargen, 1994).

482 Finally, east of the Great Basin in the Wyoming, Colorado, and the central Great

483 Plains region, record compilations in Shuman et al. (2010) and Pribyl and Shuman (2014)

484 find a consistent pattern of rapid drying after ca. 8-9 ka. Though there is substantial

485 variability in the timing and rate of these changes, many of these records show drying

486 beginning after $9.0 \mathrm{ka}$, and records that indicate abrupt drying cluster around $8 \mathrm{ka}$

487 (Williams et al., 2010). Lakes in the Rocky Mountains, in particular, show rapid water-

488 level declines at ca. 9-8 ka (Pribyl and Shuman, 2014; Shuman et al., 2010). The

489 transition at this time is also associated with a large-scale shift in North American

490 moisture gradients captured by both lake-level and pollen records east of the Great Plains,

491 which has been attributed to the rapid reduction of the Laurentide Ice Sheet and its effects

492 on atmospheric circulation (Shuman et al. 2002; Shuman et al. 2006).

493 Great Basin lake-level data document a pronounced decline in regional lake levels

494 beginning between 8 and $8.5 \mathrm{ka}$ (Figure 9). Because this compilation includes lake level

495 records of varying temporal resolution, it may not capture smaller-scale drying events.

496 However, the very clear onset of drying around $8 \mathrm{ka}$ in this compilation attests to the 
497 drying at that time being more widespread and greater in magnitude than, for example,

498 drying during the $\mathrm{B} ø$ lling-Allerød. The striking resemblance to $\mathrm{Mg} / \mathrm{Ca}$ and $\delta^{13} \mathrm{C}$ records

499 presented here suggests that our reconstruction of relative changes in infiltration rates

500 above Lehman Caves is representative of a broad portion of the Great Basin, though

501 future work will be needed to more precisely determine the spatial imprint and temporal

502 evolution of mid-Holocene drying.

5035.5 Mechanisms for wet early Holocene conditions and mid-Holocene drying

$504 \quad$ Here we consider three potential explanations for the transition from relatively

505 wet early Holocene conditions in the Great Basin to a drier mid-Holocene climate. First,

506 and most briefly, orbital changes are an unlikely explanation of wet early Holocene

507 conditions. If the shift toward slightly wetter conditions over the last $\sim 4$ ka documented

508 by Great Basin lake level records (Figure 8D) and by the growth rate record from a

509 Leviathan Cave stalagmite (Lachniet et al., 2014) is taken to represent a response to

510 insolation changes between the mid- and late Holocene (declining local summer

511 insolation and increasing winter insolation), then early Holocene insolation (high summer

512 insolation, low winter insolation) should have led to dry conditions in the Great Basin.

513 Insolation changes may drive changes in atmospheric circulation reflected in stalagmite

$514 \delta^{18} \mathrm{O}$ (Lachniet et al., 2014), but it appears that at least in the early Holocene, other

515 factors than insolation control Great Basin water balance. An alternative possibility is

516 that the higher insolation in the early Holocene resulted in an intensified North American

517 Monsoon, however, evidence for this is confined to records far south of Lehman Caves

518 (e.g. Weng and Jackson, 1999). Evidence for such a change in the region proximal to 
519 Lehman Caves is not apparent in either pollen records (Madsen et al., 2001; Rhode and

520 Madsen, 1995) or in the $\delta^{18} \mathrm{O}$ record from WR11.

521 Studies of modern climate (e.g., Schubert et al., 2004; Seager et al., 2005) have

522 found strong connections between tropical Pacific SSTs and precipitation in the western

523 U.S, raising the possibility that changes in either the mean state of the tropical Pacific or

524 in El Niño-Southern Oscillation (ENSO) variability led to the observed Holocene

525 hydrological changes in the Great Basin. Sea-surface temperature (SST) records from

526 both the eastern and western tropical Pacific based on $\mathrm{Mg} / \mathrm{Ca}$ measurements on

527 planktonic foraminifera indicate an early Holocene SST maximum (Lea et al., 2006; Stott

528 et al., 2004). A mean state of the tropical Pacific characterized by warm SSTs in the early

529 Holocene is a plausible cause of higher precipitation in the Great Basin; however,

530 alkenone-based tropical Pacific SST estimates suggest an opposite Holocene history (a

531 cooler early Holocene) (Leduc et al., 2010).

532 Holocene changes in ENSO variance may also have strong impacts on Great

533 Basin hydrology. Some reconstructions of Holocene ENSO variability suggest changes

534 that are in qualitative agreement with our records showing drying in the Great Basin after

$5358 \mathrm{ka}$ and the driest conditions between 4-6 ka. For instance, records of ENSO variance

536 from fossil surf clams from the Peruvian Coast suggest that between 7.5 and $6.7 \mathrm{ka}$, the

537 dominant spatial mode of ENSO may have produced weaker El Niño events than in the

538 early Holocene. Further, clam, foraminiferal, and coral records suggest a minimum in

539 ENSO variance at 4-5 ka (Carre et al., 2014; Cobb et al., 2013; Koutavas et al.,

540 2006). Additionally, in the modern climate, ENSO-related precipitation variance shows

541 opposite signs in the northern and southern parts of the Great Basin (Wise, 2010); if 
542 consistent through the Holocene, this could potentially account for differences in

543 hydroclimate records from different latitudes in the Great Basin. Though many Holocene

544 records show some important consistency with our reconstruction, their short duration

545 combined with the lack of agreement over whether the inferred variability in ENSO

546 variance over the Holocene is statistically significant (Cobb et al., 2013) prevents us from

547 making a firm link between our records and changes in ENSO. .

548 We instead favor a third explanation: that the presence of a remnant of the

549 Laurentide ice sheet during the early Holocene influenced storm tracks in western North

550 America, increasing winter precipitation in the interior western US. The rise of pluvial

551 lakes in the Great Basin coincident with the LGM and late-glacial has been long thought

552 to be due to the southward deflection of the westerly winter storm track by the Laurentide

553 ice sheet (Bromwich et al., 2004; COHMAP Members, 1988), but the storm track's

554 response to ice sheet retreat during the latest Pleistocene and early Holocene is poorly

555 understood. Our record indicates pronounced drying near Lehman Caves after $8.2 \mathrm{ka}$,

556 coinciding with the timing of the collapse of the remnant Laurentide ice sheet over

557 Hudson Bay (Barber et al., 1999), a precursor of the globally recorded 8.2 ka event

558 (Hughen et al. 2000; Kobashi et al. 2007; Lachniet et al. 2004; Thomas et al. 2007, and

559 others) that is thought to be the result of the draining of glacial lakes previously dammed

560 by the ice sheet. Shuman et al. (2002) showed that moisture gradients in eastern North

561 America shifted rapidly at this time, and Williams et al. (2010) find that most Great

562 Plains records showing rapid mid-Holocene drying are clustered around $8 \mathrm{ka}$. Great

563 Basin lake records compiled in Figure 8 show a similar pattern, providing corroborating

564 evidence of widespread precipitation changes in the North American interior at this time. 
565 Together, this strong temporal correspondence strongly suggests the collapse in ice sheet

566 area as a cause of the drying. Model experiments simulating $\sim 8$ ka climate with and

567 without the $8.5 \mathrm{ka}$ remnant ice sheet will be required to test this hypothesis.

568 Intriguingly, recent climate model results suggest that the connection between ice

569 sheet collapse and Great Basin hydrology may have been through changes in ENSO,

570 linking our second and third explanations above. Braconnot et al. (2011) find that the

571 early- to mid-Holocene orbital configuration favors a minimum in ENSO variance, but

572 that freshwater fluxes from melting ice sheets in the early Holocene could have offset this

573 orbital control, leading to near-modern ENSO variance in the early Holocene. Under this

574 scenario, the combination of remnant ice sheets and high freshwater fluxes in the early

575 Holocene leads to relatively high ENSO variance and wet conditions in much of the

576 Great Basin, as most of the Great Basin lies in the southern part of the ENSO

577 precipitation dipole described by Wise (2010). The lack of significant ice cover after 8

578 ka might allow mid-Holocene orbital parameters to drive a minimum in ENSO variance

579 and dry the Great Basin. Again, confirmation of this link awaits further development of

580 Holocene records of ENSO variations.

581

582 6. Conclusions

583 Elemental and stable isotope data from two Lehman Caves, NV speleothems provide

584 precisely dated records documenting the drying of the Great Basin from the deglaciation

585 through the mid-Holocene. The strong covariation of $\mathrm{Mg} / \mathrm{Ca}$ ratios and $\delta^{13} \mathrm{C}$, and their

586 agreement in two overlapping stalagmites, suggest that they track prior calcite 
587 precipitation and are robust proxies for hydroclimate change. $\mathrm{Mg} / \mathrm{Ca}$ and $\delta^{13} \mathrm{C}$ data

588 suggest wet conditions with possible slow drying between 16.4-15.0 ka. Drier conditions

589 between 15.0 and $12.7 \mathrm{ka}$, coinciding with the Bølling-Allerød warm period, are

590 suggested by a depositional hiatus in speleothem CDR3. Relatively wet conditions during

591 the Younger Dryas and earliest Holocene are indicated by both speleothems. $\mathrm{Mg} / \mathrm{Ca}$ and

$592 \delta^{13} \mathrm{C}$ values suggest a transition to slightly drier conditions at $10.3 \mathrm{ka}$, followed by

593 pronounced drying after $8.2 \mathrm{ka}$. Dry conditions then persist until the end of the record at

$594 \quad 3.8 \mathrm{ka}$.

595 The record presented here is broadly consistent with many available climate records

596 from across the Great Basin, including a new compilation of regional lake level records,

597 indicating that it accurately records the onset of large-scale mid-Holocene drying. The

598 timing of the drying's onset as well as established theories for hydroclimate drivers in the

599 Great Basin point to the collapse of the Laurentide Ice Sheet around $8.2 \mathrm{ka}$ as a possible

600 mechanism for the abrupt drying in the Basin. However, this interpretation must be

601 tested through targeted model experiments and more detailed Holocene tropical Pacific

602 records. As insolation changes would likely have led to an opposite pattern of early-to-

603 mid-Holocene change, this study of stalagmite proxies reflecting local water balance

604 suggests that even relatively small changes in ice extent or tropical SSTs can have larger

605 impacts on Great Basin hydroclimate than insolation changes.

606 7. Acknowledgements

607 We thank Larry Edwards and Xianfeng Wang for substantial contributions during 608 the early phases of this study. Ben Roberts, Gretchen Baker, and the staff of Great Basin 
609 National Park provided crucial facilitation and assistance with sampling in the field; Ken

610 Adams also assisted with initial sample collection. We also grateful to Aaron Donohoe,

611 Carrie Morrill, and Allegra LeGrande for helpful discussions of climate model results,

612 and to Bryan Hamilton for sharing oxygen isotope analyses of precipitation. We thank

613 Soumen Mallick at Brown University, Jurek Blusztajn and Scot Birdwhistell at WHOI,

614 and Rick Kayser at MIT for their help with mass spectrometry, and Wendy Salmon at the

615 Whitehead Institute for her assistance with the confocal microscope. Siyi Zhang,

616 Michaela Fendrock and Lucy Page also provided important help in the lab. This work

617 was funded by NSF EAR-1103379, the MIT EAPS Student Research Fund, and the

618 Comer Science and Education foundation.

619 Figure Captions

620 Figure 1: Map of the Great Basin (red outline) showing the largest extent of Lake

621 Bonneville (gray outline), and the location of Lehman Caves (yellow star) on the western

622 edge of the Bonneville Basin. Map modified from GeoMapApp

623 (http://www.geomapapp.org/); base map from Ryan et al., 2009.

624 Figure 2: Photograph of CDR3 and WR11. Large sample holes are U-Th samples and

625 small holes on the growth axis are stable isotope samples.

626 Figure 3: Age models (solid lines) and calculated growth rates (dotted lines) for WR11

627 (top) and CDR3 (bottom).

628 Figure 4: Stable isotope and trace element data from CDR3 (green) and WR11 (blue)

629 from 16.4 to $3.8 \mathrm{ka}$. Included are (A) U-Th age control points, (B) $\delta^{18} \mathrm{O}$, (C) $\delta^{13} \mathrm{C}$, (D)

$630 \mathrm{Mg} / \mathrm{Ca}$, and (E) $\mathrm{Sr} / \mathrm{Ca}$.

631 Figure 5: $\mathrm{Mg} / \mathrm{Ca}$ and $\mathrm{Sr} / \mathrm{Ca}$ data for cave waters collected in May 2013 (red triangles) and

632 January 2014 (blue circles). Rayleigh fractionation curves (black lines) predicted for PCP

633 are also shown. Rayleigh curves are calculated using $\mathrm{D}_{\mathrm{Sr}}=0.125$ and $\mathrm{D}_{\mathrm{Mg}}=0.0125$

634 (based on modern cave temperature and equations from Day and Henderson, 2013) and

635 initial $\mathrm{Mg} / \mathrm{Ca}$ and $\mathrm{Sr} / \mathrm{Ca}$ ratios of dripwater determined from the minimum ratios

636 measured in soil waters above the cave (this study, Supplementary Table 5). (A) $\mathrm{Mg} / \mathrm{Ca}$

637 and $\mathrm{Ca}$ concentrations; (B) $\mathrm{Sr} / \mathrm{Ca}$ and $\mathrm{Ca}$ concentrations; and (C) $\mathrm{Mg} / \mathrm{Ca}$ and $\mathrm{Sr} / \mathrm{Ca}$. In all

638 panels, increasing PCP drives values toward the right along the distillation curves. 
639 Figure 6: Trace element and stable isotope values interpolated from WR11 records to

640 demonstrate covariation or lack thereof between variables. (A) $\delta^{13} \mathrm{C}$ vs. $\mathrm{Mg} / \mathrm{Ca}$, showing 641 covariation throughout the record. (B) $\delta^{13} \mathrm{C}$ vs. Sr/Ca, showing no clear relationship. (C) $642 \mathrm{Sr} / \mathrm{Ca}$ vs. $\mathrm{Mg} / \mathrm{Ca}$, demonstrating covariation during approximately the latter half of the 643 record. (D) Covaration between $\delta^{13} \mathrm{C}$ and $\delta^{18} \mathrm{O}$.

644 Figure 7: $\delta^{18} \mathrm{O}$ records from Lehman Caves (WR11: bright blue, CDR3: gray blue) and 645 Leviathan Cave from Lachniet et al. 2014 (black). There is some agreement between

$646 \mathrm{CDR} 3$ and LC1 from 13-10 ka, but $\mathrm{LC} 1$ has substantially more positive $\delta^{18} \mathrm{O}$ values than 647 WR11 during much of the period from 10-5 ka.

648 Figure 8: Comparison of (B) $\mathrm{Mg} / \mathrm{Ca}$ and $(\mathrm{C}) \delta^{13} \mathrm{C}$ records from WR11 (blue) and CDR3 649 (green) with (D) lake level compilation data showing the percent of Great Basin lakes at 650 lowstands over time and (E) shows the area of the Laurentide Ice Sheet (LIS) over time 651 (black line) and the rate of change in LIS area over time (dashed gray line) from (Dyke, 652 2004). Age control points for WR 11 and CDR3 shown on top of figure (A). Vertical 653 gray bar indicates initiation of abrupt drying.

654

655

656

657

658

659

660

661

662

663

664 References

665 Anderson, R.S., Jass, R.B., Toney, J.L., Allen, C.D., Cisneros-Dozal, L.M., Hess, M., 666 Heikoop, J., Fessenden, J., 2008. Development of the mixed conifer forest in 667 northern New Mexico and its relationship to Holocene environmental change. Quat. 668 Res. 69, 263-275. doi:10.1016/j.yqres.2007.12.002

669 Antevs, E., 1952. Cenozoic climates of the great basin. Geol. Rundschau 40, 94-108. 
670

671

672

673

674

675

676

677

678

679

680

681

682

683

684

685

686

687

688

689

690

691

692

693

694

695

696

697

698

699

700

701

702

703
Asmerom, Y., Polyak, V., Burns, S., Rassmussen, J., 2007. Solar forcing of Holocene climate: New insights from a speleothem record, southwestern United States. Geology 35, 1. doi:10.1130/G22865A.1

Bacon, S.N., Burke, R.M., Pezzopane, S.K., Jayko, A.S., 2006. Last glacial maximum and Holocene lake levels of Owens Lake, eastern California, USA. Quat. Sci. Rev. 25, 1264-1282. doi:10.1016/j.quascirev.2005.10.014

Baker, A., Ito, E., Smart, P.L., McEwan, R.F., 1997. Elevated and variable values of 13C in speleothems in a British cave system. Chem. Geol. 136, 263-270. doi:10.1016/S0009-2541(96)00129-5

Baldini, J.U.L., McDermott, F., Baker, A., Baldini, L.M., Mattey, D.P., Railsback, L.B., 2005. Biomass effects on stalagmite growth and isotope ratios: A 20th century analogue from Wiltshire, England. Earth Planet. Sci. Lett. 240, 486-494. doi:10.1016/j.epsl.2005.09.022

Bar-Matthews, M., Ayalon, A., Matthews, A., Sass, E., Halicz, L., 1996. Carbon and oxygen isotope study of the active water-carbonate system in a karstic Mediterranean cave: Implications for paleoclimate research in semiarid regions. Geochim. Cosmochim. Acta 60, 337-347. doi:10.1016/0016-7037(95)00395-9

Barber, D.C., Jennings, A.E., Andrews, J.T., Kerwin, M.W., Morehead, M.D., 1999. Forcing of the cold event of 8,200 years ago by catastrophic drainage of Laurentide lakes. Nature 400, 13-15. doi:10.1038/22504

Benson, L.V., Lund, S.P., Smoot, J.P., Rhode, D.E., Spencer, R.J., Verosub, K.L., Louderback, L. a., Johnson, C. a., Rye, R.O., Negrini, R.M., 2011. The rise and fall of Lake Bonneville between 45 and $10.5 \mathrm{ka}$. Quat. Int. 235, 57-69. doi:10.1016/j.quaint.2010.12.014

Braconnot, P., Luan, Y., Brewer, S., Zheng, W., 2011. Impact of Earth's orbit and freshwater fluxes on Holocene climate mean seasonal cycle and ENSO characteristics. Clim. Dyn. 38, 1081-1092. doi:10.1007/s00382-011-1029-x

Bromwich, D.H., Toracinta, E.R., Wei, H., Oglesby, R.J., Fastook, J.L., Hughes, T.J., 2004. Polar MM5 Simulations of the Winter Climate of the Laurentide Ice Sheet at the LGM*. J. Clim. 17, 3415-3433. doi:10.1175/15200442(2004)017<3415:PMSOTW >2.0.CO;2

Broughton, J.M., Byers, D.A., Bryson, R.A., Eckerle, W., Madsen, D.B., 2008. Did climatic seasonality control late Quaternary artiodactyl densities in western North America? Quat. Sci. Rev. 27, 1916-1937. doi:10.1016/j.quascirev.2008.07.005 
704

705

706

707

708

709

710

711

712

713

714

715

716

717

718

719

720

721

722

723

724

725

726

727

728

729

730

731

732

733

734

735

736

737
Broughton, J.M., Madsen, D.B., Quade, J., 2000. Fish Remains from Homestead Cave and Lake Levels of the Past 13,000 Years in the Bonneville Basin. Quat. Res. 53, 392-401. doi:10.1006/qres.2000.2133

Carre, M., Sachs, J.P., Purca, S., Schauer, A.J., Braconnot, P., Falcon, R.A., Julien, M., Lavallee, D., 2014. Holocene history of ENSO variance and asymmetry in the eastern tropical Pacific. Science (80-. ). 345, 1045-1048.

doi:10.1126/science. 1252220

Cheng, H., Lawrence Edwards, R., Shen, C.-C., Polyak, V.J., Asmerom, Y., Woodhead, J., Hellstrom, J., Wang, Y., Kong, X., Spötl, C., Wang, X., Calvin Alexander, E., 2013. Improvements in 230Th dating, 230Th and 234U half-life values, and $\mathrm{U}-\mathrm{Th}$ isotopic measurements by multi-collector inductively coupled plasma mass spectrometry. Earth Planet. Sci. Lett. 371-372, 82-91.

doi:10.1016/j.epsl.2013.04.006

Cobb, K.M., Westphal, N., Sayani, H.R., Watson, J.T., Di Lorenzo, E., Cheng, H., Edwards, R.L., Charles, C.D., 2013. Highly variable El Niño-Southern Oscillation throughout the Holocene. Science 339, 67-70. doi:10.1126/science.1228246

COHMAP Members, 1988. Climatic changes of the last 18,000 years: observations and model simulations. Science 241, 1043-52. doi:10.1126/science.241.4869.1043

Currey, D.R., 1990. Quaternary palaeolakes in the evolution of semidesert basins, with special emphasis on Lake Bonneville and the Great Basin, U.S.A. Palaeogeogr. Palaeoclimatol. Palaeoecol. doi:10.1016/0031-0182(90)90113-L

Davis, O.K., 1999. Pollen analysis of Tulare Lake, California: Great Basin-like vegetation in Central California during the full-glacial and early Holocene. Rev. Palaeobot. Palynol. 107, 249-257. doi:10.1016/S0034-6667(99)00020-2

Day, C.C., Henderson, G.M., 2013. Controls on trace-element partitioning in caveanalogue calcite. Geochim. Cosmochim. Acta 120, 612-627. doi:10.1016/j.gca.2013.05.044

Denniston, R.F., DuPree, M., Dorale, J. a., Asmerom, Y., Polyak, V.J., Carpenter, S.J., 2007. Episodes of late Holocene aridity recorded by stalagmites from Devil's Icebox Cave, central Missouri, USA. Quat. Res. 68, 45-52. doi:10.1016/j.yqres.2007.04.001

Dyke, A.S., 2004. An outline of North American Deglaciation with emphasis on central and northern Canada, in: Ehlers, J., Gibbard, P.L. (Eds.), Quaternary Glaciations Extent and Chronology: Part II: North America. Elsevier, pp. 373-424. 
738

739

740

741

742

743

744

745

746

747

748

749

750

751

752

753

754

755

756

757

758

759

760

761

762

763

764

765

766

767

768

769

770

771

772

Fairchild, I.J., Baker, A., 2012. Speleothem Science: From Process to Past Environments, Speleothem Science: From Process to Past Environments. Wiley-Blackwell. doi:10.1002/9781444361094

Fairchild, I.J., Smith, C.L., Baker, A., Fuller, L., Spötl, C., Mattey, D., McDermott, F., 2006. Modification and preservation of environmental signals in speleothems. EarthScience Rev. 75, 105-153. doi:10.1016/j.earscirev.2005.08.003

Frumkin, A., Stein, M., 2004. The Sahara-East Mediterranean dust and climate connection revealed by strontium and uranium isotopes in a Jerusalem speleothem. Earth Planet. Sci. Lett. 217, 451-464. doi:10.1016/S0012-821X(03)00589-2

García, A.F., Stokes, M., 2006. Late Pleistocene highstand and recession of a small, highaltitude pluvial lake, Jakes Valley, central Great Basin, USA. Quat. Res. 65, 179186. doi:10.1016/j.yqres.2005.08.025

Gascoyne, M., 1992. Palaeoclimate determination from cave calcite deposits. Quat. Sci. Rev. 11, 609-632. doi:10.1016/0277-3791(92)90074-I

Godsey, H.S., Oviatt, C.G., Miller, D.M., Chan, M. a., 2011. Stratigraphy and chronology of offshore to nearshore deposits associated with the Provo shoreline, Pleistocene Lake Bonneville, Utah. Palaeogeogr. Palaeoclimatol. Palaeoecol. 310, 442-450. doi:10.1016/j.palaeo.2011.08.005

Goede, A., Green, D.C., Harmon, R.S., 1982. Isotopic composition of precipitation, cave drips, and actively forming speleothems at three Tasmanian cave sites. Helictite 20, $17-27$.

Harmon, R.S., Thompson, P., Schwarcz, H.P., Ford, D.C., 1978. Late Pleistocene paleoclimates of North America as inferred from stable isotope studies of speleothems. Quat. Res. 9, 54-70. doi:10.1016/0033-5894(78)90082-0

Hart, W.S., Quade, J., Madsen, D.B., Kaufman, D.S., Oviatt, C.G., 2004. The 87Sr/86Sr ratios of lacustrine carbonates and lake-level history of the Bonneville paleolake system. Geol. Soc. Am. Bull. 116, 1107. doi:10.1130/B25330.1

Hasbargen, J., 1994. A Holocene Paleoclimatic and Environmental Record from Stoneman Lake, Arizona. Quat. Res. 42, 188-196. doi:10.1006/qres.1994.1068

Hendy, C.., 1971. The isotopic geochemistry of speleothems-I. The calculation of the effects of different modes of formation on the isotopic composition of speleothems and their applicability as palaeoclimatic indicators. Geochim. Cosmochim. Acta. doi:10.1016/0016-7037(71)90127-X

Hendy, C.H., Wilson, A.T., 1968. Palaeoclimatic Data from Speleothems. Nature 219, 48-51. doi:10.1038/219048a0 
773

774

775

776

777

778

779

780

781

782

783

784

785

786

787

788

789

790

791

792

793

794

795

796

797

798

799

800

801

802

803

804

805

806

807

Huang, Y., Fairchild, I.J., 2001. Partitioning of Sr2+ and Mg2+ into calcite under karstanalogue experimental conditions. Geochim. Cosmochim. Acta 65, 47-62. doi:10.1016/S0016-7037(00)00513-5

Hughen, K.A., 2000. Synchronous Radiocarbon and Climate Shifts During the Last Deglaciation. Science (80-. ). 290, 1951-1954. doi:10.1126/science.290.5498.1951

Jaffey, A.H., Flynn, K.F., Glendenin, L., Bentley, C., Essling, A.M., 1971. Precision Measurement of Half-Lives and Specific Activities of 235U and 238U. Phys. Rev. C 4, 1889-1906.

Jochum, K.P., Scholz, D., Stoll, B., Weis, U., Wilson, S. a., Yang, Q., Schwalb, A., Börner, N., Jacob, D.E., Andreae, M.O., 2012. Accurate trace element analysis of speleothems and biogenic calcium carbonates by LA-ICP-MS. Chem. Geol. 318319, 31-44. doi:10.1016/j.chemgeo.2012.05.009

Johnson, K., Hu, C., Belshaw, N., Henderson, G., 2006. Seasonal trace-element and stable-isotope variations in a Chinese speleothem: The potential for high-resolution paleomonsoon reconstruction. Earth Planet. Sci. Lett. 244, 394-407. doi:10.1016/j.epsl.2006.01.064

Kanner, L.C., Buenning, N.H., Stott, L.D., Timmermann, A., Noone, D., 2014. The role of soil processes in $\delta 18 \mathrm{O}$ terrestrial climate proxies. Global Biogeochem. Cycles 28, 239-252. doi:10.1002/2013GB004742

Kobashi, T., Severinghaus, J.P., Brook, E.J., Barnola, J.-M., Grachev, A.M., 2007. Precise timing and characterization of abrupt climate change 8200 years ago from air trapped in polar ice. Quat. Sci. Rev. 26, 1212-1222. doi:10.1016/j.quascirev.2007.01.009

Koutavas, A., DeMenocal, P.B., Olive, G.C., Lynch-Stieglitz, J., 2006. Mid-Holocene El Niño-Southern Oscillation (ENSO) attenuation revealed by individual foraminifera in eastern tropical Pacific sediments. Geology 34, 993. doi:10.1130/G22810A.1

Lachniet, M.S., 2009. Climatic and environmental controls on speleothem oxygenisotope values. Quat. Sci. Rev. 28, 412-432. doi:10.1016/j.quascirev.2008.10.021

Lachniet, M.S., Asmerom, Y., Burns, S.J., Patterson, W.P., Polyak, V.J., Seltzer, G.O., 2004. Tropical response to the $8200 \mathrm{yr}$ B.P. cold event? Speleothem isotopes indicate a weakened early Holocene monsoon in Costa Rica. Geology 32, 957. doi:10.1130/G20797.1

Lachniet, M.S., Denniston, R.F., Asmerom, Y., Polyak, V.J., 2014. Orbital control of western North America atmospheric circulation and climate over two glacial cycles. Nat. Commun. 5, 3805. doi:10.1038/ncomms4805 
808

809

810

811

812

813

814

815

816

817

818

819

820

821

822

823

824

825

826

827

828

829

830

831

832

833

834

835

836

837

838

839

840

841

842

Lawrence Edwards, R., Chen, J.H., Wasserburg, G.J., 1987. 238U234U230Th232Th systematics and the precise measurement of time over the past 500,000 years. Earth Planet. Sci. Lett. 81, 175-192. doi:10.1016/0012-821X(87)90154-3

Lea, D.W., Pak, D.K., Belanger, C.L., Spero, H.J., Hall, M.A., Shackleton, N.J., 2006. Paleoclimate history of Galápagos surface waters over the last 135,000yr. Quat. Sci. Rev. 25, 1152-1167. doi:10.1016/j.quascirev.2005.11.010

Leduc, G., Schneider, R., Kim, J.-H., Lohmann, G., 2010. Holocene and Eemian sea surface temperature trends as revealed by alkenone and $\mathrm{Mg} / \mathrm{Ca}$ paleothermometry. Quat. Sci. Rev. 29, 989-1004. doi:10.1016/j.quascirev.2010.01.004

Li, H.C., Ku, T.L., You, C.F., Cheng, H., Edwards, R.L., Ma, Z.B., Tsai, W.S., Li, M.D., 2005. $87 \mathrm{Sr} / 86 \mathrm{Sr}$ and $\mathrm{Sr} / \mathrm{Ca}$ in speleothems for paleoclimate reconstruction in Central China between 70 and $280 \mathrm{kyr}$ ago. Geochim. Cosmochim. Acta 69, 3933-3947. doi:10.1016/j.gca.2005.01.009

Louderback, L. a., Rhode, D.E., 2009. 15,000 Years of vegetation change in the Bonneville basin: the Blue Lake pollen record. Quat. Sci. Rev. 28, 308-326. doi:10.1016/j.quascirev.2008.09.027

Lundeen, Z., Brunelle, A., Burns, S.J., Polyak, V., Asmerom, Y., 2013. A speleothem record of Holocene paleoclimate from the northern Wasatch Mountains, southeast Idaho, USA. Quat. Int. 310, 83-95. doi:10.1016/j.quaint.2013.03.018

Lyle, M., Heusser, L., Ravelo, C., Yamamoto, M., Barron, J., Diffenbaugh, N.S., Herbert, T., Andreasen, D., 2012. Out of the tropics: the Pacific, Great Basin lakes, and late Pleistocene water cycle in the western United States. Science 337, 1629-33. doi:10.1126/science. 1218390

Madsen, D.B., Rhode, D., Grayson, D.K., Broughton, J.M., Livingston, S.D., Hunt, J., Quade, J., Schmitt, D.N., Shaver, M.W., 2001. Late Quaternary environmental change in the Bonneville basin, western USA. Palaeogeogr. Palaeoclimatol. Palaeoecol. 167, 243-271. doi:10.1016/S0031-0182(00)00240-6

McGee, D., Quade, J., Edwards, R.L., Broecker, W.S., Cheng, H., Reiners, P.W., Evenson, N., 2012. Lacustrine cave carbonates: Novel archives of paleohydrologic change in the Bonneville Basin (Utah, USA). Earth Planet. Sci. Lett. 351-352, 182194. doi:10.1016/j.eps1.2012.07.019

Mickler, P.J., Banner, J.L., Stern, L., Asmerom, Y., Edwards, R.L., Ito, E., 2004. Stable isotope variations in modern tropical speleothems: Evaluating equilibrium vs. kinetic isotope effects. Geochim. Cosmochim. Acta 68, 4381-4393. doi:10.1016/j.gca.2004.02.012 
843 Mickler, P.J., Stern, L. a., Banner, J.L., 2006. Large kinetic isotope effects in modern

$844 \quad$ speleothems. Geol. Soc. Am. Bull. 118, 65-81. doi:10.1130/B25698.1

845 Mühlinghaus, C., Scholz, D., Mangini, A., 2007. Modelling stalagmite growth and $\delta 13 C$

846 as a function of drip interval and temperature. Geochim. Cosmochim. Acta 71,

847 2780-2790. doi:10.1016/j.gca.2007.03.018

848 Mühlinghaus, C., Scholz, D., Mangini, A., 2009. Modelling fractionation of stable

849 isotopes in stalagmites. Geochim. Cosmochim. Acta 73, 7275-7289.

850 doi:10.1016/j.gca.2009.09.010

851 Munroe, J.S., Laabs, B.J.C., 2013. Latest Pleistocene history of pluvial Lake Franklin,

852

853 northeastern Nevada, USA. Geol. Soc. Am. Bull. 125, 322-342. doi:10.1130/B30696.1

854 Munroe, J.S., Laabs, B.J.C., 2013. Temporal correspondence between pluvial lake

855

856 highstands in the southwestern US and Heinrich Event 1. J. Quat. Sci. 28, 49-58. doi:10.1002/jqs. 2586

857 Murchison, S.B., 1989. Fluctuation History of Great Salt Lake, Utah During the Last $858 \quad 13,000$ Years. University of Utah.

859

Orland, I.J., Burstyn, Y., Bar-Matthews, M., Kozdon, R., Ayalon, A., Matthews, A.,

860

861

862 Valley, J.W., 2014. Seasonal climate signals (1990-2008) in a modern Soreq Cave stalagmite as revealed by high-resolution geochemical analysis. Chem. Geol. 363,

863

864

865

Oster, J.L., Ibarra, D.E., Harris, C.R., Maher, K., 2012. Influence of eolian deposition and rainfall amounts on the U-isotopic composition of soil water and soil minerals.

Geochim. Cosmochim. Acta 88, 146-166. doi:10.1016/j.gca.2012.04.004

866

867

868

Oster, J.L., Montañez, I.P., Sharp, W.D., Cooper, K.M., 2009. Late Pleistocene California droughts during deglaciation and Arctic warming. Earth Planet. Sci. Lett. 288, 434443. doi:10.1016/j.epsl.2009.10.003

869

870

Oviatt, C.G., 1997. Lake Bonneville fluctuations and global climate change. Geology 25,

871 Oviatt, C.G., Currey, D.R., Sack, D., 1992. Radiocarbon chronology of Lake Bonneville,

872

873 Eastern Great Basin, USA. Palaeogeogr. Palaeoclimatol. Palaeoecol. 99, 225-241. doi:10.1016/0031-0182(92)90017-Y

874 Oviatt, C.G., Miller, D.M., McGeehin, J.P., Zachary, C., Mahan, S., 2005. The Younger

875 Dryas phase of Great Salt Lake, Utah, USA. Palaeogeogr. Palaeoclimatol.

876 Palaeoecol. 219, 263-284. doi:10.1016/j.palaeo.2004.12.029 
877

878

879

880

881

882

883

884

885

886

887

888

889

890

891

892

893

894

895

896

897

898

899

900

901

902

903

904

905

906

907

908

909

910

Patrickson, S.J., Sack, D., Brunelle, A.R., Moser, K. a., 2010. Late Pleistocene to early Holocene lake level and paleoclimate insights from Stansbury Island, Bonneville basin, Utah. Quat. Res. 73, 237-246. doi:10.1016/j.yqres.2009.12.006

Polyak, V.J., Asmerom, Y., 2005. Orbital control of long-term moisture in the southwestern USA. Geophys. Res. Lett. 32, 1-4. doi:10.1029/2005GL023919

Polyak, V.J., Rasmussen, J.B.T., Asmerom, Y., 2004. Prolonged wet period in the southwestern United States through the Younger Dryas. Geology 32, 5. doi:10.1130/G19957.1

Power, M.J., Whitlock, C., Bartlein, P.J., 2011. Postglacial fire, vegetation, and climate history across an elevational gradient in the Northern Rocky Mountains, USA and Canada. Quat. Sci. Rev. 30, 2520-2533. doi:10.1016/j.quascirev.2011.04.012

Pribyl, P., Shuman, B.N., 2014. A computational approach to Quaternary lake-level reconstruction applied in the central Rocky Mountains, Wyoming, USA. Quat. Res. 82, 249-259. doi:10.1016/j.yqres.2014.01.012

Quade, J., Forester, R.M., Pratt, W.L., Carter, C., 1998. Black Mats, Spring-Fed Streams, and Late-Glacial-Age Recharge in the Southern Great Basin. Quat. Res. 49, 129148. doi:10.1006/qres.1997.1959

Rasmussen, S.O., Andersen, K.K., Svensson, a. M., Steffensen, J.P., Vinther, B.M., Clausen, H.B., Siggaard-Andersen, M.-L., Johnsen, S.J., Larsen, L.B., Dahl-Jensen, D., Bigler, M., Röthlisberger, R., Fischer, H., Goto-Azuma, K., Hansson, M.E., Ruth, U., 2006. A new Greenland ice core chronology for the last glacial termination. J. Geophys. Res. 111, D06102. doi:10.1029/2005JD006079

Rhode, D., Madsen, D.B., 1995. Late Wisconsin/early Holocene vegetation in the Bonneville Basin. Quarternary Int. 44, 246-256. doi:10.1006/qres.1995.1069

Ryan, W.B.F., Carbotte, S.M., Coplan, J.O., O'Hara, S., Melkonian, A., Arko, R., Weissel, R.A., Ferrini, V., Goodwillie, A., Nitsche, F., Bonczkowski, J., Zemsky, R., 2009. Global Multi-Resolution Topography synthesis. Geochemistry, Geophys. Geosystems 10, n/a-n/a. doi:10.1029/2008GC002332

Schubert, S.D., Suarez, M.J., Pegion, P.J., Koster, R.D., Bacmeister, J.T., 2004. Causes of Long-Term Drought in the U.S. Great Plains. J. Clim. 17, 485-503. doi:10.1175/1520-0442(2004)017<0485:COLDIT>2.0.CO;2

Schwarcz, H.P., Harmon, R.S., Thompson, P., Ford, D.C., 1976. Stable isotope studies of fluid inclusions in speleothems and their paleoclimatic significance. Geochim. Cosmochim. Acta 40, 657-665. doi:10.1016/0016-7037(76)90111-3 
911 Seager, R., Kushnir, Y., Herweijer, C., Naik, N., Velez, J., 2005. Modeling of Tropical

$912 \quad$ Forcing of Persistent Droughts and Pluvials over Western North America: 1856-

913 2000*. J. Clim. 18, 4065-4088. doi:10.1175/JCLI3522.1

914 Shakun, J.D., Burns, S.J., Clark, P.U., Cheng, H., Edwards, R.L., 2011. Milankovitch915 paced Termination II in a Nevada speleothem? Geophys. Res. Lett. 38, n/a-n/a.

916 doi:10.1029/2011GL048560

917 Shen, C.-C., Lawrence Edwards, R., Cheng, H., Dorale, J. a, Thomas, R.B., Bradley

918

919

920

921

922

923

924

925

926

927

928

929

930

931

932

933

934

935

936

937

938

939

940

941

942

943

944

Shuman, B., 2002. Parallel climate and vegetation responses to the early Holocene collapse of the Laurentide Ice Sheet. Quat. Sci. Rev. 21, 1793-1805. doi:10.1016/S0277-3791(02)00025-2

Shuman, B., Huang, Y., Newby, P., Wang, Y., 2006. Compound-specific isotopic analyses track changes in seasonal precipitation regimes in the Northeastern United States at ca 8200calyrBP. Quat. Sci. Rev. 25, 2992-3002. doi:10.1016/j.quascirev.2006.02.021

Shuman, B., Pribyl, P., Minckley, T.A., Shinker, J.J., 2010. Rapid hydrologic shifts and prolonged droughts in Rocky Mountain headwaters during the Holocene. Geophys. Res. Lett. 37, n/a-n/a. doi:10.1029/2009GL042196

Sinclair, D.J., Banner, J.L., Taylor, F.W., Partin, J., Jenson, J., Mylroie, J., Goddard, E., Quinn, T., Jocson, J., Miklavič, B., 2012. Magnesium and strontium systematics in tropical speleothems from the Western Pacific. Chem. Geol. 294-295, 1-17. doi:10.1016/j.chemgeo.2011.10.008

Stott, L., Cannariato, K., Thunell, R., Haug, G.H., Koutavas, A., Lund, S., 2004. Decline of surface temperature and salinity in the western tropical Pacific Ocean in the Holocene epoch. Nature 431, 56-9. doi:10.1038/nature02903

Thomas, E.R., Wolff, E.W., Mulvaney, R., Steffensen, J.P., Johnsen, S.J., Arrowsmith, C., White, J.W.C., Vaughn, B., Popp, T., 2007. The 8.2ka event from Greenland ice cores. Quat. Sci. Rev. 26, 70-81. doi:10.1016/j.quascirev.2006.07.017

Tremaine, D.M., Froelich, P.N., 2013. Speleothem trace element signatures: A hydrologic geochemical study of modern cave dripwaters and farmed calcite. Geochim. Cosmochim. Acta 121, 522-545. doi:10.1016/j.gca.2013.07.026 
945 Wagner, J.D.M., Cole, J.E., Beck, J.W., Patchett, P.J., Henderson, G.M., Barnett, H.R., 946 2010. Moisture variability in the southwestern United States linked to abrupt glacial

947 climate change. Nat. Geosci. 3, 110-113. doi:10.1038/ngeo707

948 Weng, C., Jackson, S.T., 1999. Late Glacial and Holocene vegetation history and

949 paleoclimate of the Kaibab Plateau, Arizona. Palaeogeogr. Palaeoclimatol.

$950 \quad$ Palaeoecol. 153, 179-201. doi:10.1016/S0031-0182(99)00070-X

951 Williams, J.W., Shuman, B., Bartlein, P.J., Diffenbaugh, N.S., Webb, T., 2010. Rapid,

952 time-transgressive, and variable responses to early Holocene midcontinental drying

953 in North America. Geology 38, 135-138. doi:10.1130/G30413.1

954 Wise, E.K., 2010. Spatiotemporal variability of the precipitation dipole transition zone in

955 the western United States. Geophys. Res. Lett. doi:10.1029/2009GL042193

956 Yardley, B.W.D., 1986. The continental crust: Its composition and evolution by S. R.

957 Taylor and S. M. McClennan, Blackwell Scientific Publications, Oxford, 1985. No.

958 of pages: $312+$ XV pp. Price: $£ 16.80$ (soft covers). Geol. J. 21, 85-86.

959 doi:10.1002/gj.3350210116

960 Yonge, C.J., Ford, D.C., Gray, J., Schwarcz, H.P., 1985. Stable isotope studies of cave

961 seepage water. Chem. Geol. Isot. Geosci. Sect. 58, 97-105. doi:10.1016/0168-

962 9622(85)90030-2

963

964 
Figure 1

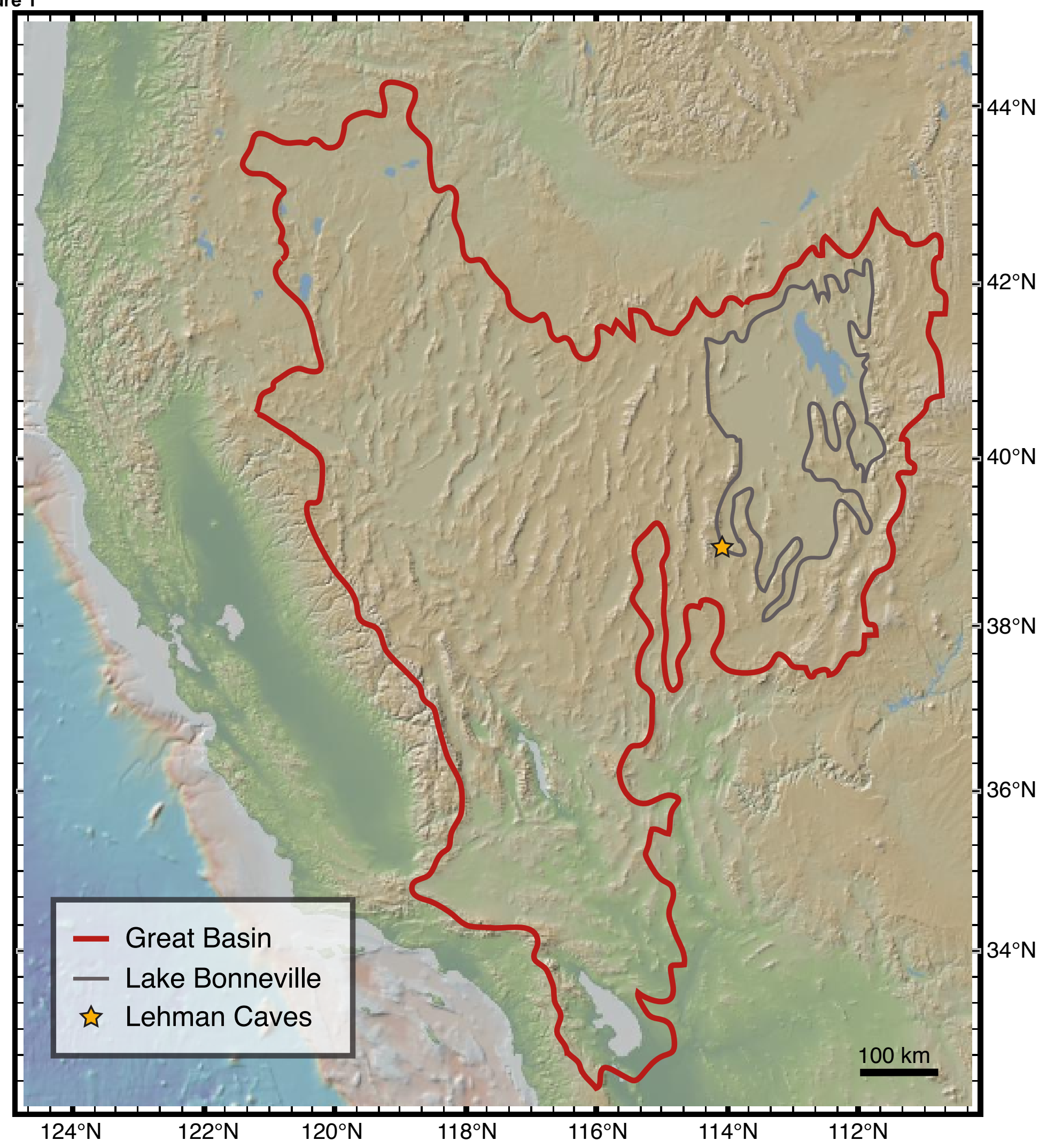




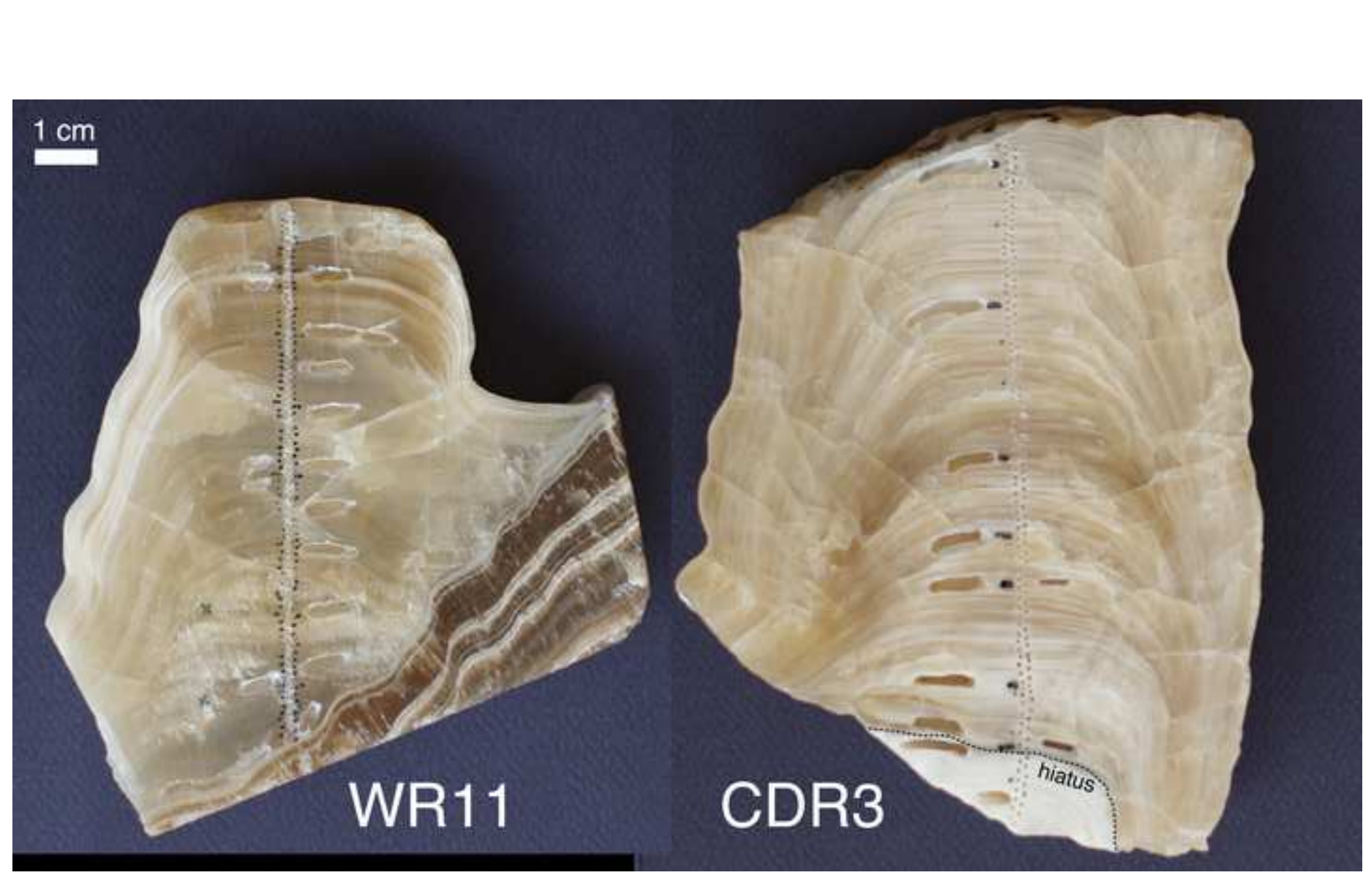

E

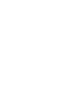



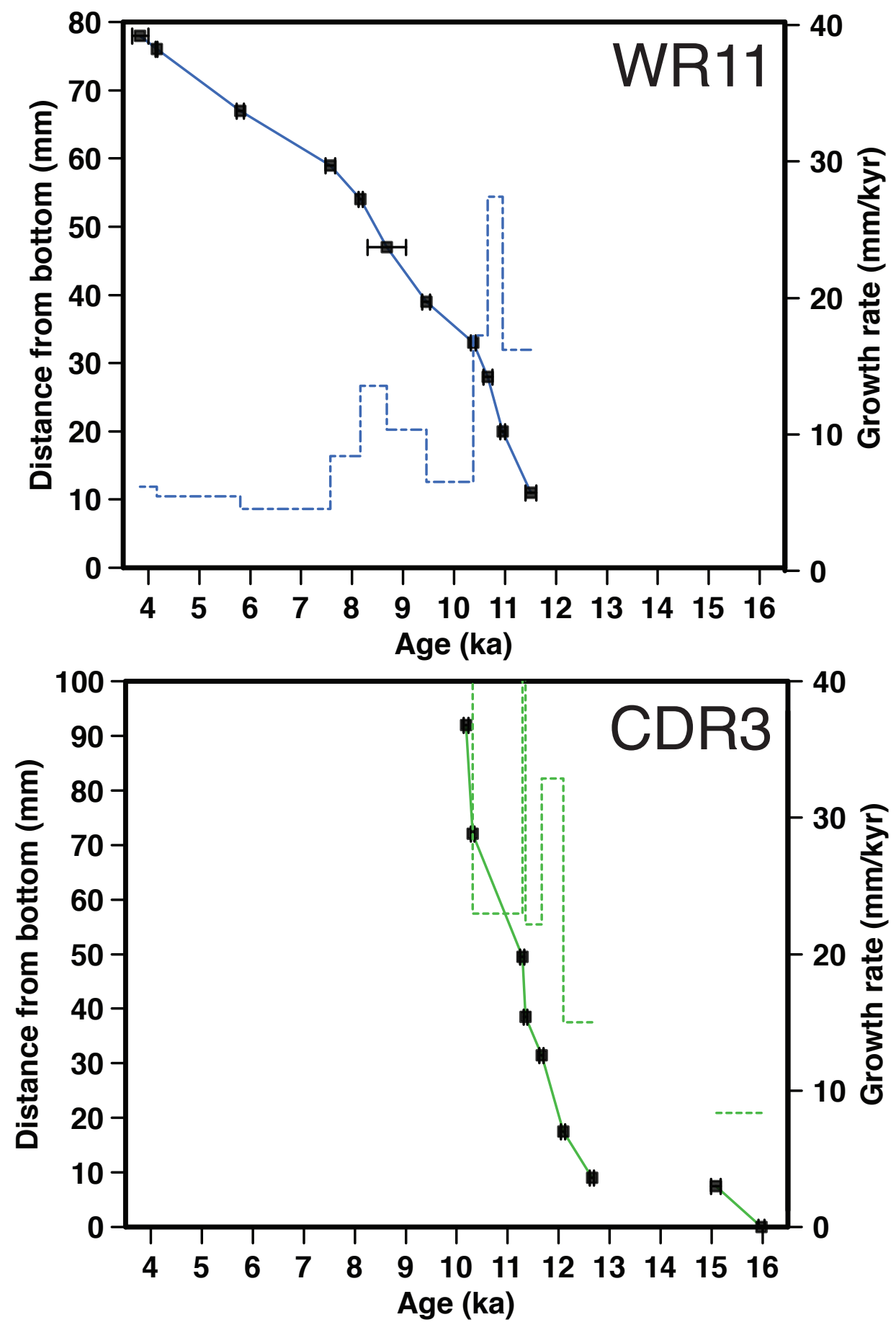
Figure 4

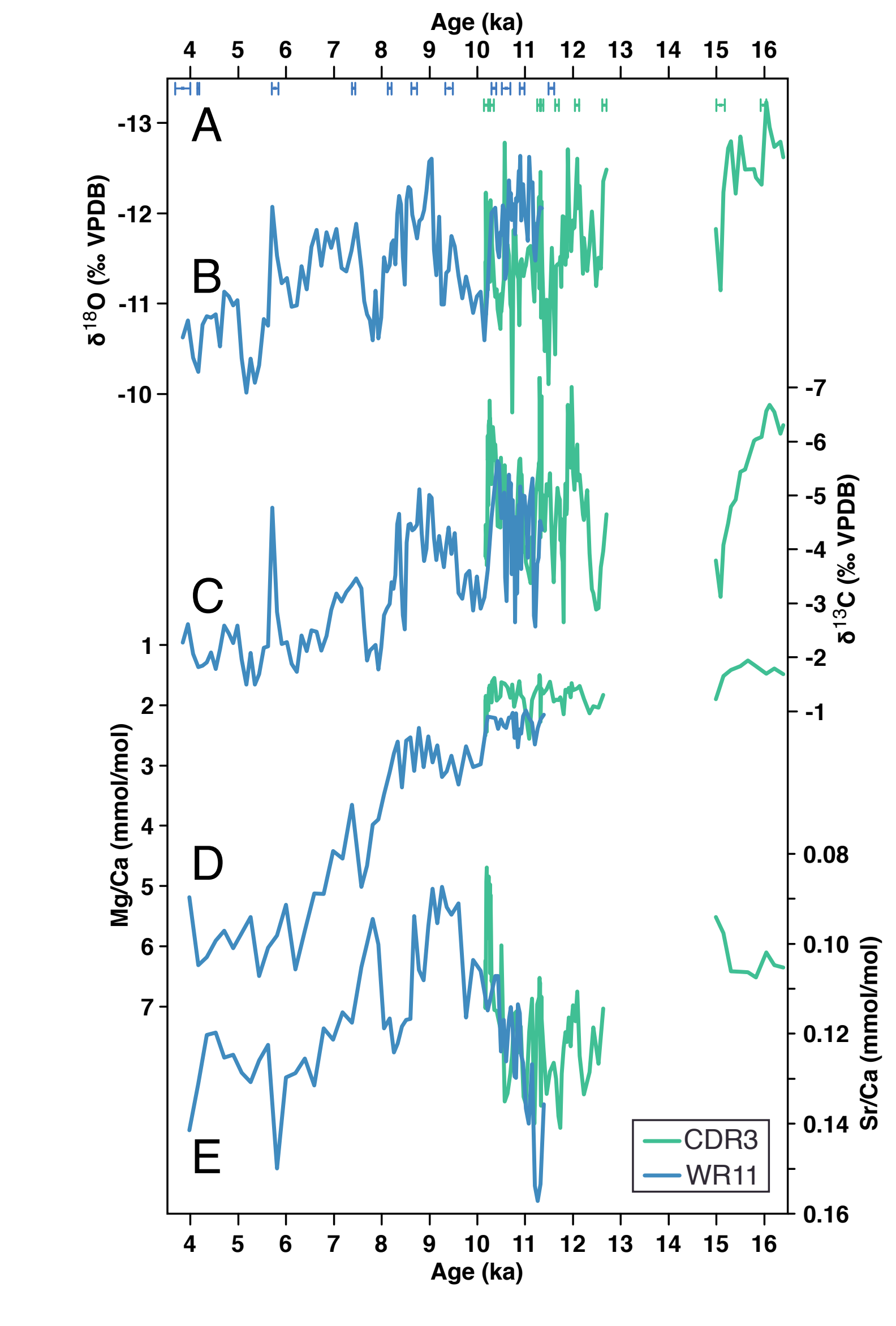

Age (ka)

列

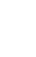


Figure 5
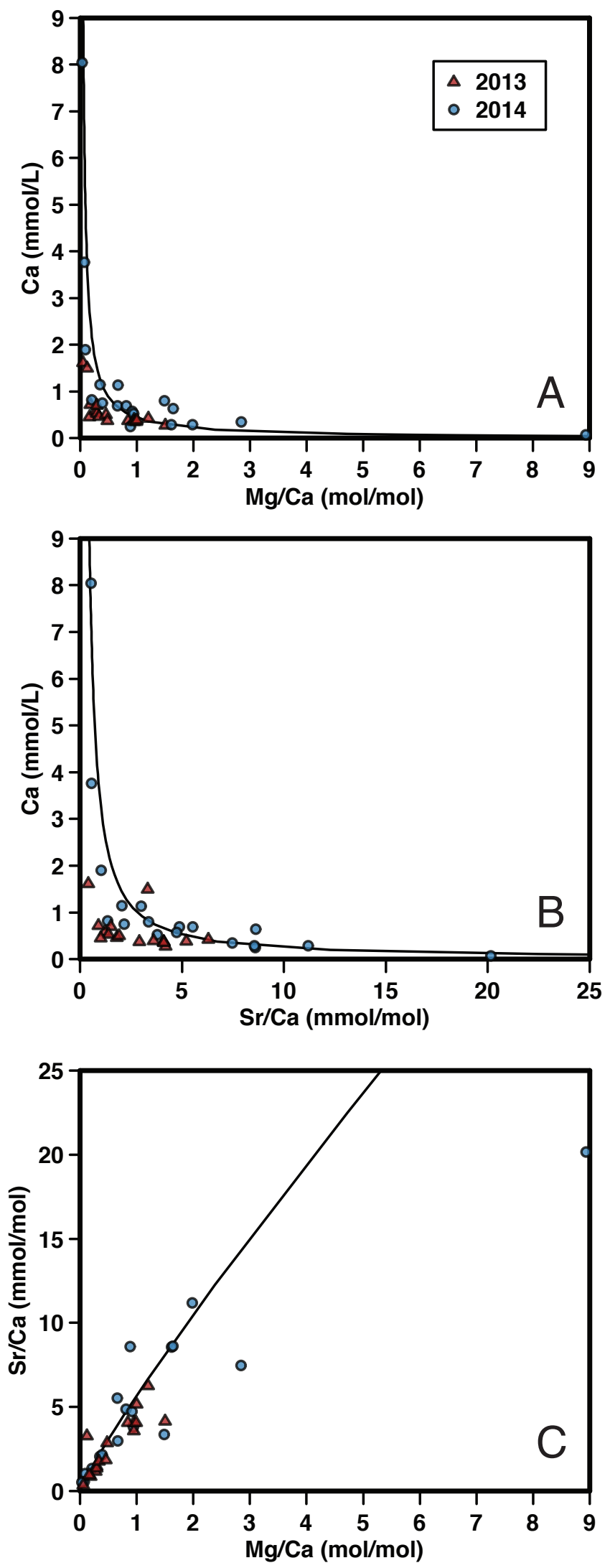
Figure 6
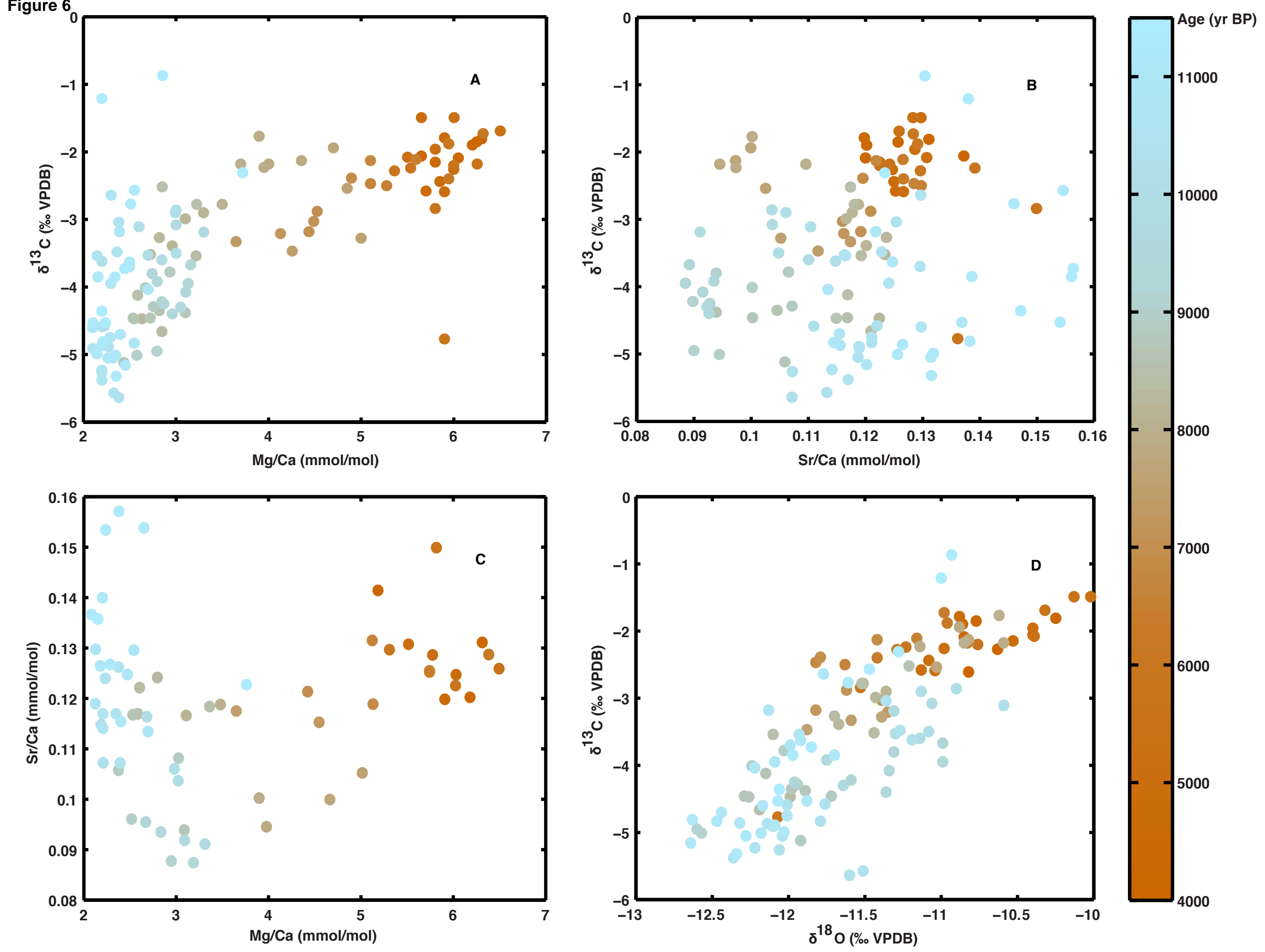
Figure 7

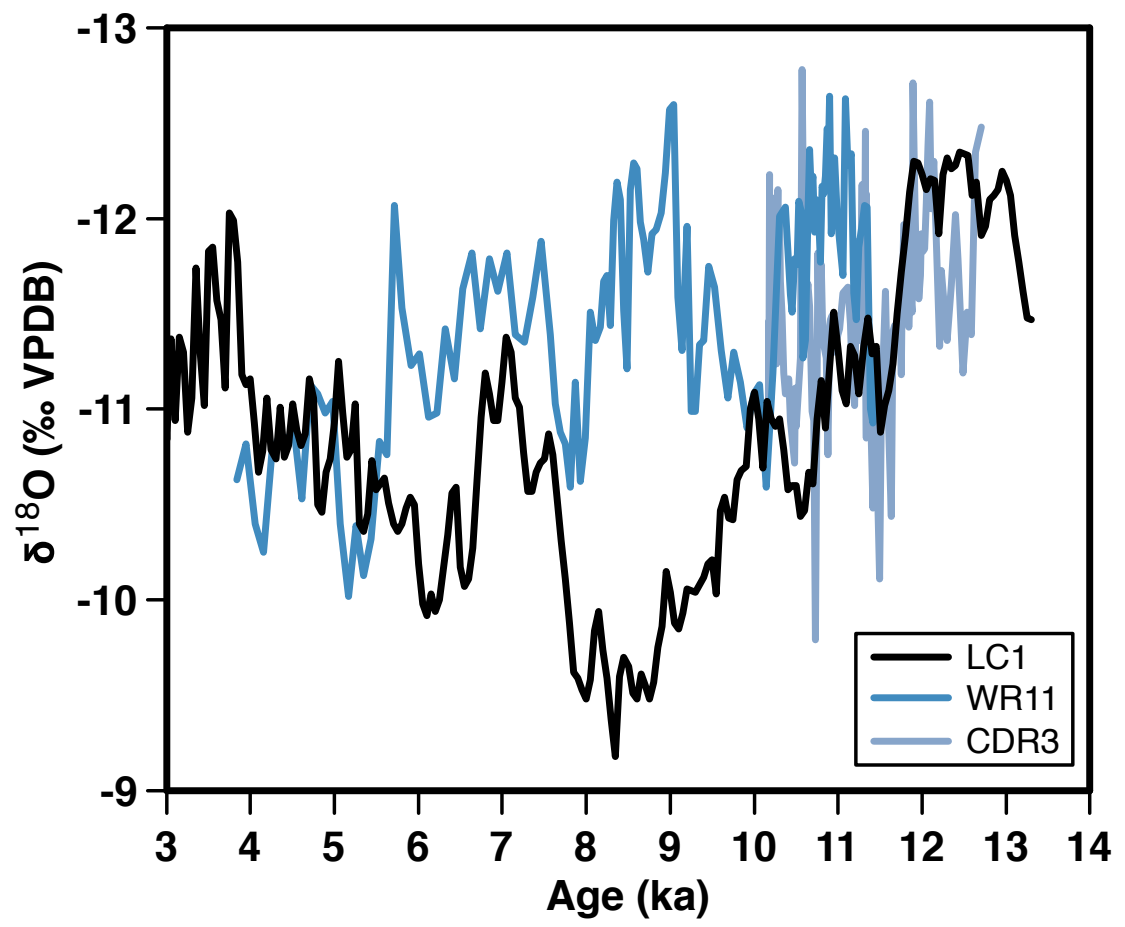




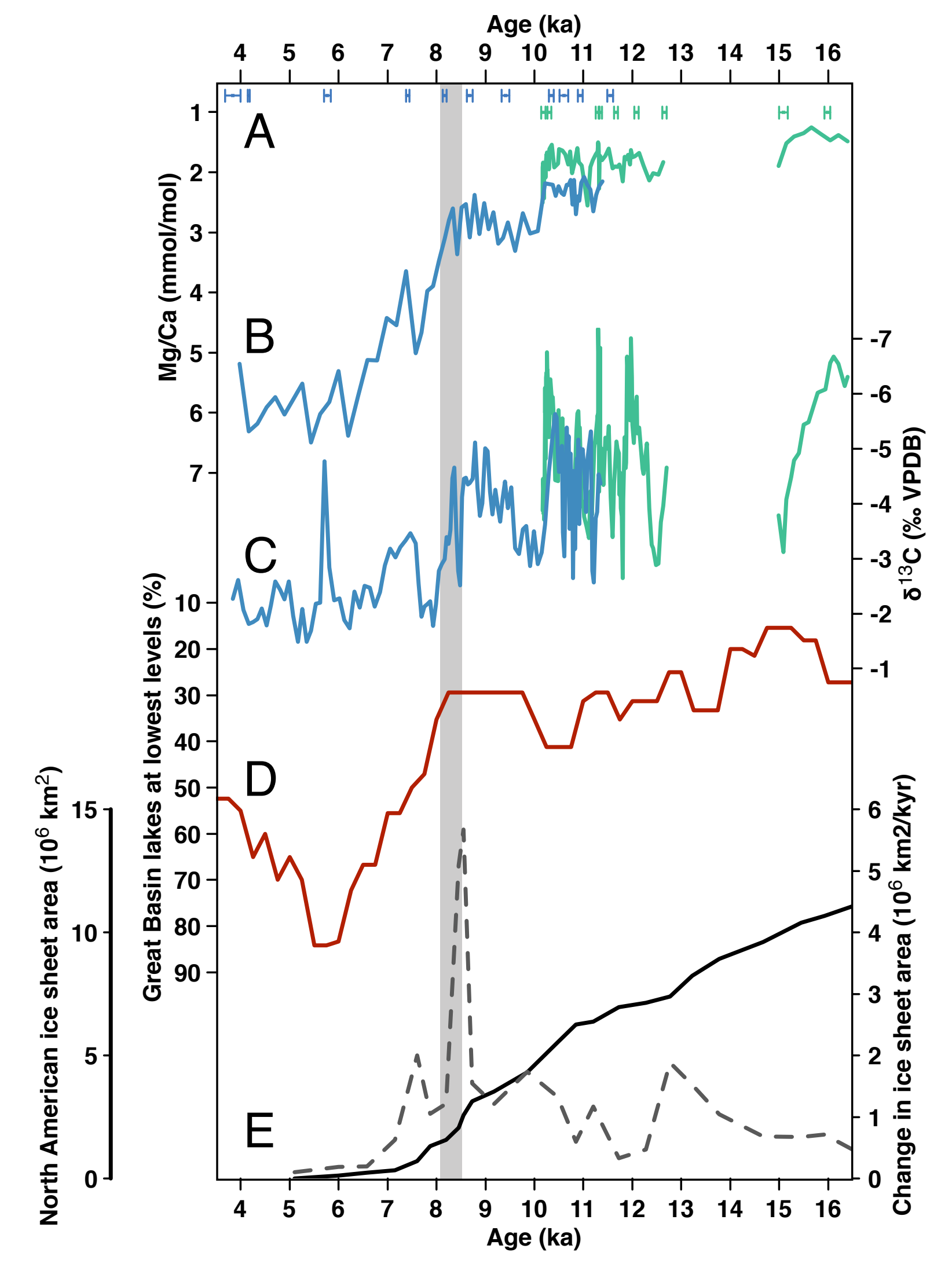

Figure 8

Age (ka)

.

更

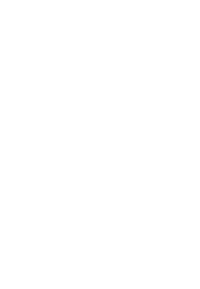

$$
\text { (n) }
$$$$
\text { . }
$$ 